\title{
Banks as patient fixed-income investors
}

\author{
Samuel G. Hanson ${ }^{\mathrm{a}, *}$, Andrei Shleifer ${ }^{\mathrm{a}}$, Jeremy C. Stein ${ }^{\mathrm{a}}$, Robert W. Vishny ${ }^{\mathrm{b}}$ \\ a Harvard University, USA \\ ${ }^{\mathrm{b}}$ University of Chicago, USA
}

\section{A R T I C L E I N F O}

\section{Article history:}

Received 11 August 2014

Received in revised form

20 January 2015

Accepted 26 February 2015

Available online 2 July 2015

\section{JEL classification:}

G01

G21

G23

\section{Keywords:}

Commercial banking

Shadow banking

Safe money-like claims

\begin{abstract}
A B S T R A C T
We examine the business model of traditional commercial banks when they compete with shadow banks. While both types of intermediaries create safe "money-like" claims, they go about this in different ways. Traditional banks create money-like claims by holding illiquid fixed-income assets to maturity, and they rely on deposit insurance and costly equity capital to support this strategy. This strategy allows bank depositors to remain "sleepy": they do not have to pay attention to transient fluctuations in the market value of bank assets. In contrast, shadow banks create money-like claims by giving their investors an early exit option requiring the rapid liquidation of assets. Thus, traditional banks have a stable source of funding, while shadow banks are subject to runs and fire-sale losses. In equilibrium, traditional banks have a comparative advantage at holding fixed-income assets that have only modest fundamental risk but are illiquid and have substantial transitory price volatility, whereas shadow banks tend to hold relatively liquid assets.
\end{abstract}

(c) 2015 Elsevier B.V. All rights reserved.

\section{Introduction}

What defines the business model of traditional banks in a modern financial system where they compete with marketbased intermediaries such as "shadow banks"? To address this question, we present a model in which traditional and shadow banks coexist in the marketplace. We begin with the premise that the primary function of both types of intermediaries is to create safe, "money-like" claims that are of value to households because they are useful for transactions purposes (Gorton and Pennacchi, 1990; Stein, 2012; DeAngelo and Stulz, 2015). However, traditional banks and shadow banks invest in different portfolios of assets to support such claims. Traditional banks hold illiquid fixed-income assets, such as long-term securities and loans, which may be subject to substantial short-run price fluctuations but have little long-run fundamental risk. To hold such assets, they maintain a costly equity cushion in their capital structure but also rely on deposit insurance and other elements of the government safety net. This strategy allows bank depositors to remain "sleepy": they do not have to pay attention to transient fluctuations in the mark-to-market value of bank assets and never run. In contrast, the shadow banking system-intermediation chains that often involve money market funds-relies less on the government safety net and costly equity capital. For shadow banks, manufacturing money-like claims requires them to hold more liquid assets that can be easily sold at only a modest discount should their investors decide to exit.

\footnotetext{
We are grateful to seminar participants at the 2014 NBER Spring Corporate Finance Meeting, the 2014 NBER Macro, Money and Financial Frictions Summer Institute, the Federal Reserve Bank of San Francisco, Harvard University, NYU Stern, UC Berkeley Haas, and USC Marshall for helpful comments, as well as to Malcolm Baker, John Campbell, Eduardo Dávila, Harry DeAngelo, Doug Diamond, Mihir Desai, Gary Gorton, Robin Greenwood, Bengt Holmstrom, Arvind Krishnamurthy, David Scharfstein, René Stulz, Adi Sunderam, Paul Tucker, Annette Vissing-Jorgensen, and Yao Zeng for valuable suggestions. We also thank Yueran Ma for excellent research assistance. An Internet Appendix is available at http://www.people.hbs.edu/shanson/banksIA.pdf.

* Corresponding author. Tel.: +1 6174956137 .

E-mail address: shanson@hbs.edu (S.G. Hanson).
} 
We see asset fire sales as a key source of illiquidity. In our model, asset liquidations temporarily push prices below fundamental value. So, on the one hand, traditional banks' more stable deposit funding structure has an advantage: it enables them to hold investments to maturity, riding out transitory valuation shocks until prices revert to fundamental values. On the other hand, funding stability is expensive due to higher costs of equity capital and regulatory compliance. Because the endogenous fire-sale discount is greater when shadow banks hold more of an asset, this tradeoff pins down the equilibrium holdings of any given asset across intermediary types. The most liquid assets are held entirely by shadow banks, while less liquid (but fundamentally low risk) assets are held entirely by commercial banks. When an asset is held by both intermediary types, the relative holdings of banks and shadow banks must be such that the expected loss to a shadow bank from liquidating an asset at a temporary discount to fundamental value is just balanced by the added cost a traditional bank pays for more stable funding.

This logic leads to our main finding: for traditional banks there is a critical synergy between the asset and liability sides of the balance sheet. Issuing stable money-like claims is complementary to investing in fixed-income assets that have only modest fundamental risk but are relatively illiquid and may have substantial exposure to interim fire-sale risk and the accompanying transitory price volatility. In our view, this synergy between funding structure and asset choice is at the heart of the modern business of commercial banking and is what fundamentally distinguishes traditional banks from shadow banks: traditional banks are patient investors that can invest in illiquid fixed-income assets with little risk of being interrupted before maturity.

While our formal model emphasizes fire sales (Shleifer and Vishny, 1992), our message would also emerge in other models in which early liquidation can occur at prices below fundamental value. For example, early liquidation can be costly in models that combine noise trader shocks with limited arbitrageur risk-bearing capacity (DeLong, Shleifer, Summers, and Waldmann, 1990; Shleifer and Vishny, 1997). Alternatively, liquidation costs could come from adverse selection (Gorton and Pennacchi, 1990; Dang, Gorton, and Holmström, 2013). The general point is that transitory nonfundamental movements in asset prices are central to understanding financial intermediation and especially the connection between the asset and liability sides of intermediary balance sheets. A stable funding structure is an important source of comparative advantage for holding assets that are vulnerable to transitory price movements. In this way, traditional banks are similar to deep-pocket arbitrageurs who specialize in fixed-income assets.

It is important to stress that what our model actually pins down is not literally the roles of different types of legal institutions (e.g., commercial banks or money market funds) but rather the equilibrium mix between two intermediation strategies that use risky assets to back money-like claims. For any given asset, our model asks how much of its total supply will be intermediated using a "stable funding strategy" that relies on an equity cushion and insured deposits, and how much will be intermediated using an "unstable funding strategy" in which investors protect the safety of their claims with an early exit option. The interdependencies between asset characteristics and funding strategies are the true equilibrium outcomes of our model. In reality, there is a close correspondence between funding strategies and specific legal forms. In particular, when intermediaries are distinguished by their access to deposit insurance and the lender of last resort, commercial banks are the dominant institutional vehicle for implementing the stable funding strategy. And we primarily associate the unstable funding strategy with the so-called shadow banking system.

We motivate our analysis in Section 2 by presenting some stylized facts about the assets and liabilities of modern commercial banks. We show that commercial banks have significant holdings of relatively illiquid long-term fixed-income securities, such as asset-backed securities, mortgage-backed securities, and corporate bonds. At the same time, banks generally avoid the most liquid debt securities, such as short-term money market paper and Treasuries, as well as highly risky securities such as equities. These facts offer important clues for understanding the business of commercial banking. In Section 3, we present our model of alternative strategies for supporting money-like claims and show how commercial and shadow banks coexist in equilibrium. We then turn to some evidence bearing on our model's key predictions about the connections between the asset and liability sides of intermediary balance sheets.

Section 4 briefly takes a historical look at the US commercial banking industry. We find that prior to the introduction of federal deposit insurance, US commercial banks followed a strategy that resembles that of shadow banks today. Like today, a commercial bank in, say, 1870, was in the business of taking deposits and thereby offering its customers safe money-like claims. At the same time, commercial banks in 1870 held assets with much shorter maturities and experienced more runs than they do today. The shift of commercial bank assets to longer-maturity loans and long-term securities can be linked to the introduction of deposit insurance, as our model predicts.

Another way to examine the predictions of the model is to look at the asset and liability structures of financial institutions more broadly. In Section 5, we use the Financial Accounts of the United States (formerly the Flow of Funds) to provide some contemporary aggregate evidence addressing the model's key predictions. In the data, looking across fixed-income asset classes, today's traditional banks have a larger market share in more illiquid assets, be they loans or securities. Similarly, looking across financial intermediary types, intermediaries with more stable funding such as traditional banks have asset portfolios that are more illiquid. In this way, our model yields a novel synthesis of several aggregate facts about the structure of financial intermediation.

Our paper relates to several strands in the literature. Our starting point is the liability-centric view of banks, which holds that an important part of banks' value comes from their ability to manufacture safe money-like liabilities. ${ }^{1}$ This view helps make sense of the fact that, in contrast to nonfinancial firms, banks have capital structures that are highly homogeneous in

${ }^{1}$ This view has its roots in Gorton and Pennacchi (1990). Recent papers in this vein include Dang, Gorton, and Holmstrom (2013), DeAngelo and Stulz (2015), Gennaioli, Shleifer, and Vishny (2013), Stein (2012), and Krishnamurthy and Vissing-Jorgensen (2015). 
both the cross-section and the time series: they are almost always heavily deposit-financed. At the same time, this liabilitycentric view does not explain why banks hold illiquid loans and securities. ${ }^{2}$ To the contrary, the liability-centric view has led some observers to advocate narrow banking, whereby bank-created money is backed entirely by safe liquid assets such as Treasury bills (see Pennacchi, 2012). As a positive description of commercial banking, however, narrow banking is very far from what we observe in the world and is unlikely to break even. The challenge is to understand why banks simultaneously finance themselves with deposits and hold long-term and illiquid fixed-income assets.

A second group of theories explicitly addresses the question of what ties together the asset and liability sides of bank balance sheets-i.e., why is it that the same institutions that create private money choose to back their safe money-like claims not by investing in T-bills but rather by investing in loans and other relatively illiquid assets? What is the synergy between these two activities? In a classic contribution, Diamond and Dybvig (1983) argue that banks allow households who are unsure of the timing of their consumption needs to invest more efficiently in long-lived projects that are costly to interrupt early. ${ }^{3}$ Diamond and Dybvig emphasize deposit insurance as the source of stability that keeps depositors sleepy and prevents runs. We use this observation to address a question not taken up by Diamond and Dybvig: what types of assets are optimal for deposit-insured banks to hold?

Several other studies have focused on potential complementarities between banks' assets and liabilities. Diamond and Rajan (2001) suggest that the fragility of runnable bank deposits disciplines bank management, enhancing the value of illiquid bank loans. Kashyap, Rajan, and Stein (2002) highlight the similarities between demand deposits and loan commitments, and the ability of an institution that offers both to economize on costly liquidity buffers; Gatev and Strahan (2006) provide supporting evidence for this view. Gennaioli, Shleifer, and Vishny (2013) also argue that a central function of banks is to provide money-like claims but focus on asset-side diversification and tranching as technologies for backing such safe liabilities. DeAngelo and Stulz (2015) emphasize diversification and risk-management strategies to reduce the riskiness of bank assets.

Our work also connects with several other themes. First, a number of papers explore the joint roles of banks and securities markets in allocating credit and satisfying the demand for liquidity (Holmstrom and Tirole, 1997; Diamond, 1997). Second, several papers study the shadow banking system and its role in the financial crisis (Coval, Jurek, and Stafford, 2009; Shleifer and Vishny, 2010; Gorton and Metrick, 2011; Diamond and Rajan, 2011; Stein, 2012; Gennaioli, Shleifer, and Vishny, 2012, 2013; Kacperczyk and Schnabl, 2013; Krishnamurthy, Nagel, and Orlov, 2014; Chernenko and Sunderam, 2014; Sunderam, 2015; Moreira and Savov, 2014). Finally, a few recent papers measure the mismatch between the liquidity of intermediary assets and liabilities (Brunnermeier, Gorton, and Krishnamurthy, 2014; Bai et al., 2015).

\section{Motivating evidence}

\subsection{Fact 1: Bank liabilities are highly homogeneous}

Banks' liability structures are highly homogeneous: banks are almost always financed largely with deposits. This finding holds both in the cross-section and over time. In the cross-section, Table 1 shows various balance sheet items as a share of total assets at the end of 2012 for US commercial banks. To assess the cross-sectional heterogeneity in balance sheets, we show the valueweighted average share, the 90th percentile, and the 10th percentile for each item. To avoid the idiosyncrasies associated with the smallest banks, we focus on banks with assets greater than $\$ 1$ billion. Table 1 reveals a high degree of homogeneity in the amount of deposit funding. The average bank finances $76 \%$ of its assets with deposits. A bank at the 90 th percentile in terms of the distribution is $89 \%$ deposit-financed, only a bit more than a bank at the 10 th percentile, which is $74 \%$ deposit-financed. A similar pattern holds in the time series for the banking industry as a whole. Fig. 1 shows the evolution of the aggregate balance sheets of US banks from 1896 to 2012. As shown in Panel A, banks' liability structures have been very stable over the past 115 years. Deposits have financed $80 \%$ of bank assets on average with an annual standard deviation of just $8 \%$.

These patterns are in sharp contrast to those for nonfinancial firms, where capital structure tends to be far less determinate, both within industries and over time. This suggests that for banks-unlike nonfinancials, and counter to the spirit of Modigliani and Miller (1958)-an important part of their economic value creation takes place on the liability side of the balance sheet, via deposit-taking. This is broadly consistent with the literature that has followed Gorton and Pennacchi (1990).

\subsection{Fact 2: Bank assets are more heterogeneous}

There is considerably more heterogeneity on the asset side of bank balance sheets and in particular in their mix between loans and securities. In the 2012 cross-section, a bank at the 10th percentile of the distribution had a ratio of securities to assets of $6.9 \%$, while for a bank at the 90 th percentile, the ratio was almost six times higher at $40.7 \% .{ }^{4}$ One interpretation of this heterogeneity is as follows: while lending is obviously very important for a majority of banks, a bank's scale need not be

\footnotetext{
${ }^{2}$ Asset-centric theories of banking, such as those that see banks as delegated monitors (Diamond, 1984), do not draw a distinction between banks and other nonbank lenders, which we see as critical.

3 Taken literally, the Diamond-Dybvig model does not admit a rationale for banks to hold marketable securities; see Jacklin (1987). Taken less literally, the model makes no predictions on the kinds of assets banks would hold.

4 These figures on securities holdings do not include banks' holdings of cash and reverse repo, which averaged $10.2 \%$ and $4.1 \%$ of assets on a valueweighted basis in 2012 .
} 
Table 1

US commercial bank balance sheet composition, 2012.

This table illustrates the balance sheet composition of US commercial banks as of December 31, 2012 using Call Report data. We restrict attention to commercial banks with assets greater than $\$ 1$ billion. Collapsing all commercial banks owned by a single bank holding company into a single banking firm, our $\$ 1$ billion size cutoff leaves us with 501 banking firms as of year-end 2012. The table shows the value-weighted average balance sheet shares and (the equal-weighted) 90th and 10th percentiles of bank balance sheet shares. Panel A shows results for all banks. Panel B shows results for highly capitalized banks whose equity-to-assets ratio exceeds the industry median.

\begin{tabular}{|c|c|c|c|c|c|c|}
\hline \multirow[b]{3}{*}{ Loans (gross) } & \multicolumn{3}{|c|}{ Panel A: All banks } & \multicolumn{3}{|c|}{ Panel B: Highly capitalized banks } \\
\hline & VW Average & 90th \%-tile & 10th \%-tile & VW Average & 90th \%-tile & 10th \%-tile \\
\hline & $52.9 \%$ & $78.1 \%$ & $42.2 \%$ & $58.1 \%$ & $78.1 \%$ & $43.0 \%$ \\
\hline Real estate & $25.2 \%$ & $62.0 \%$ & $19.7 \%$ & $27.4 \%$ & $62.2 \%$ & $17.6 \%$ \\
\hline Residential & $16.2 \%$ & $26.1 \%$ & $3.6 \%$ & $18.1 \%$ & $25.1 \%$ & $2.9 \%$ \\
\hline Commercial & $9.0 \%$ & $43.1 \%$ & $9.7 \%$ & $9.3 \%$ & $43.8 \%$ & $6.4 \%$ \\
\hline C\&I & $9.7 \%$ & $20.7 \%$ & $3.0 \%$ & $11.1 \%$ & $23.4 \%$ & $3.1 \%$ \\
\hline Consumer & $9.3 \%$ & $9.2 \%$ & $0.2 \%$ & $10.4 \%$ & $11.0 \%$ & $0.1 \%$ \\
\hline Other & $8.7 \%$ & $8.8 \%$ & $0.1 \%$ & $9.2 \%$ & $8.5 \%$ & $0.1 \%$ \\
\hline Less reserves & $-1.2 \%$ & $-0.6 \%$ & $-1.9 \%$ & $-1.3 \%$ & $-0.5 \%$ & $-2.0 \%$ \\
\hline Loans (net) & $51.7 \%$ & $75.9 \%$ & $41.7 \%$ & $56.8 \%$ & $76.0 \%$ & $42.4 \%$ \\
\hline Liquid assets & $35.2 \%$ & $50.9 \%$ & $16.4 \%$ & $30.6 \%$ & $49.1 \%$ & $15.6 \%$ \\
\hline Cash and reserves & $10.2 \%$ & $16.8 \%$ & $2.2 \%$ & $9.0 \%$ & $14.1 \%$ & $2.2 \%$ \\
\hline Reverse repos & $4.1 \%$ & $1.4 \%$ & $0.0 \%$ & $2.2 \%$ & $1.8 \%$ & $0.0 \%$ \\
\hline Securities & $20.8 \%$ & $40.7 \%$ & $6.9 \%$ & $19.3 \%$ & $36.9 \%$ & $6.5 \%$ \\
\hline Treasuries & $1.6 \%$ & $1.4 \%$ & $0.0 \%$ & $1.9 \%$ & $1.2 \%$ & $0.0 \%$ \\
\hline Agencies & $1.2 \%$ & $10.2 \%$ & $0.0 \%$ & $0.9 \%$ & $7.7 \%$ & $0.0 \%$ \\
\hline MBS Passthroughs & $6.8 \%$ & $14.5 \%$ & $0.2 \%$ & $7.3 \%$ & $14.5 \%$ & $0.3 \%$ \\
\hline CMOs and CMBS & $5.2 \%$ & $14.9 \%$ & $0.0 \%$ & $4.6 \%$ & $13.3 \%$ & $0.0 \%$ \\
\hline Other securities & $6.1 \%$ & $13.4 \%$ & $0.3 \%$ & $4.6 \%$ & $12.6 \%$ & $0.2 \%$ \\
\hline Trading assets (net) & $3.8 \%$ & $0.1 \%$ & $0.0 \%$ & $2.9 \%$ & $0.1 \%$ & $0.0 \%$ \\
\hline Other assets & $9.3 \%$ & $11.6 \%$ & $3.5 \%$ & $9.7 \%$ & $12.4 \%$ & $3.9 \%$ \\
\hline TOTAL ASSETS & $100.0 \%$ & & & $100.0 \%$ & & \\
\hline Deposits & $75.6 \%$ & $88.9 \%$ & $73.6 \%$ & $76.0 \%$ & $86.0 \%$ & $70.3 \%$ \\
\hline Transaction & $10.2 \%$ & $22.6 \%$ & $4.0 \%$ & $9.5 \%$ & $19.7 \%$ & $2.0 \%$ \\
\hline Savings & $44.5 \%$ & $63.0 \%$ & $23.7 \%$ & $48.3 \%$ & $60.5 \%$ & $23.6 \%$ \\
\hline Time & $9.4 \%$ & $38.3 \%$ & $8.6 \%$ & $9.2 \%$ & $39.1 \%$ & $8.6 \%$ \\
\hline Foreign & $11.5 \%$ & $0.0 \%$ & $0.0 \%$ & $9.1 \%$ & $0.4 \%$ & $0.0 \%$ \\
\hline Repos & $3.4 \%$ & $6.2 \%$ & $0.0 \%$ & $2.6 \%$ & $5.4 \%$ & $0.0 \%$ \\
\hline Subordinated debt & $1.0 \%$ & $0.5 \%$ & $0.0 \%$ & $0.9 \%$ & $0.7 \%$ & $0.0 \%$ \\
\hline Other borrowed money & $5.7 \%$ & $9.4 \%$ & $0.0 \%$ & $5.4 \%$ & $9.7 \%$ & $0.0 \%$ \\
\hline Other liabilities & $2.9 \%$ & $2.2 \%$ & $0.3 \%$ & $2.6 \%$ & $2.8 \%$ & $0.4 \%$ \\
\hline Equity & $11.4 \%$ & $14.9 \%$ & $8.2 \%$ & $12.5 \%$ & $16.2 \%$ & $10.6 \%$ \\
\hline TOTAL LIABILITIES \& EQUITY & $100.0 \%$ & & & $100.0 \%$ & & \\
\hline
\end{tabular}

pinned down by the nature of its lending opportunities. Rather, in some cases, it seems that a bank's size is determined by its deposit franchise, and that taking deposits as given, its problem becomes one of how to best invest them. Again, this liability-centric perspective is very different from how we are used to thinking about nonfinancial firms, whose scale is almost always presumed to be driven by their opportunities on the asset side of the balance sheet.

\subsection{Fact 3: Bank securities portfolios do not seem to be precautionary liquidity buffers}

While banks are quite heterogeneous in their mix between loans and securities, within the category of securities, banks appear to have relatively well-defined preferences. As can be seen in Table 1 and Panel A of Fig. 2, banks hold little in the way of Treasury and agency securities: these two categories accounted for just 7.7\% and 5.8\% of total securities holdings on a valueweighted basis in 2012. The bulk of their holdings are in agency mortgage-backed securities (MBS) and other types of mortgage-linked securities such as collateralized mortgage obligations (CMOs) and commercial mortgage-backed securities (CMBS): these collectively accounted for 57.7\% of securities holdings in 2012. Also important is the "other" category, which includes corporate and municipal bonds as well as asset-backed securities, and which accounted for $29.3 \%$ of holdings in 2012.

This composition of banks' securities portfolios is not what one would expect if banks were simply holding securities as a highly liquid buffer stock against unexpected deposit outflows or loan commitment drawdowns. It also appears at odds with the narrowbanking premise that one can profitably exploit a deposit franchise simply by taking deposits and parking them in T-bills. Rather, it looks as if banks are purposefully taking on some mix of duration, credit, and prepayment risk in order to earn a spread relative to T-bills. Indeed, over the period from 1984 to 2012, the average spread on banks' securities portfolio relative to bills was $1.73 \%$.

In this vein, it is interesting to ask how profitable banks would be in a counterfactual world in which their deposit-taking behavior was exactly the same, but instead of allocating their securities holdings as they actually do, they followed a narrow-banking strategy of investing only in T-bills. The profitability of a narrow bank that takes deposits $D E P$ at a rate $R_{D E P}$ 

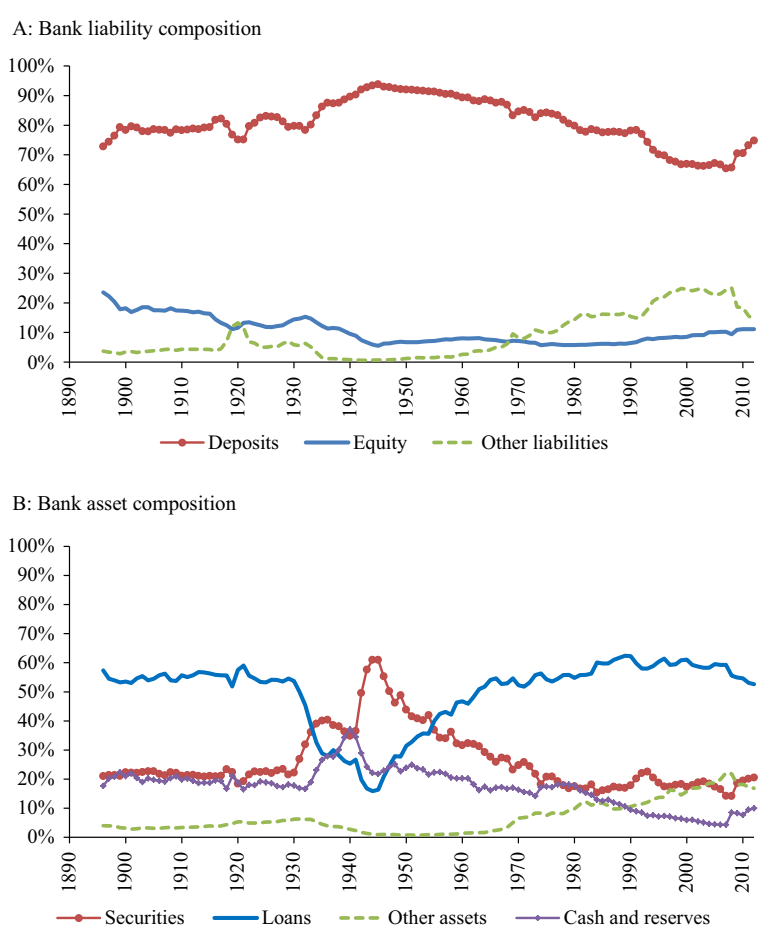

Fig. 1. Data on US commercial bank balance sheets, 1896-2012. This figure shows the evolution of the aggregate balance sheet of US commercial banks from 1896 to 2012. All figures are in book terms and are scaled by total assets. The series for 1896-1918 are based on data for "all banks" from All Bank Statistics, United States, 1896-1955 (Board of Governors of the Federal Reserve System, 1959). The series for 1919-1933 are based on Federal Reserve member banks from Banking and Monetary Statistics, 1919-1941 (Board of Governors of the Federal Reserve System, 1943). The series for 1934-2012 are based on all insured commercial banks from the Federal Deposit Insurance Corporation's (FDIC) Historical Statistics on Banking available at http://www2. fdic.gov/hsob/.

and invests them in T-bills paying $R_{F}$, while incurring deposit-related noninterest expenses of NONINTEXP (e.g., employee salaries, bricks-and-mortar expenses associated with bank branches, and other operating expenses) and earning depositrelated noninterest income of NONINTINC (e.g., services charges on deposit accounts) is given by

$$
\Pi=\left(R_{F}-R_{D E P}\right)+\frac{N O N I N T I N C}{D E P}-\frac{N O N I N T E X P}{D E P} .
$$

We carry out this calculation for the aggregate commercial banking industry from 1984 to 2012 . To compute the gross deposit spread, $R_{F}-R_{D E P}$, we use the rate on 3-month Treasury bills as our proxy for $R_{F}$ and compute $R_{D E P}$ from Call Reports as the interest paid on deposits divided by deposits. Deposit rates appear to embed a significant convenience premium relative to short-term market rates: the gross deposit spread averages $0.87 \%$ over our 29 -year sample. We next add the noninterest income that banks earn from service charges on deposit accounts from Call Reports. This averages $0.49 \%$ of deposits over our sample. Finally, we subtract the noninterest expense associated with deposit-taking. This is not directly available from Call Reports: banks report their total noninterest expense, but we are interested only in that portion attributable to deposit-taking. ${ }^{5}$ As detailed in the Internet Appendix, we use a hedonic-regression approach to infer the expenses associated with deposit-taking. Although these expenses have trended down due to advances in information technology, they remain substantial, averaging $1.30 \%$ of deposits over the past 29 years.

Combining these pieces as in Eq. (1), we estimate the average profitability of narrow banking between 1984 and 2012 to be $0.06 \%$ of deposits $(0.06 \%=0.87 \%+0.49 \%-1.30 \%){ }^{6}$ In other words, the interest rate differential between deposits and short-term marketable rates and the associated fee income is largely offset by the direct costs of operating a deposit-taking franchise. Given these numbers, it is perhaps not surprising that banks choose to invest in riskier securities that earn a spread relative to T-bills. Of course, the large costs of deposit-taking that we document ultimately represent an endogenous choice for traditional banks, and so must be explained as an equilibrium outcome in any fully satisfactory model. For example, banks could always choose to hold down costs by offering fewer physical branch services to their customers, similarly to money market mutual funds. We return to the endogeneity of deposit-taking expenses below.

\footnotetext{
${ }^{5}$ In 2012 , banks had noninterest operating expenses equal to $2.96 \%$ of total assets. These can be decomposed into wage and salary expenses of $1.32 \%$, building occupancy expenses of $0.32 \%$, and other expenses of $1.32 \%$.

${ }^{6}$ This $0.06 \%$ figure is probably an upper bound on the profitability of narrow banking. As explained in the Internet Appendix, our methodology for attributing bank expenses to different activities leaves an unallocated cost, which can be thought of as fixed overhead. This overhead cost averages $0.63 \%$ of deposits from 1984 to 2012. If 50\% of this amount is allocated back to deposit-taking, the estimated profitability of narrow banking drops to $-0.25 \%$.
} 

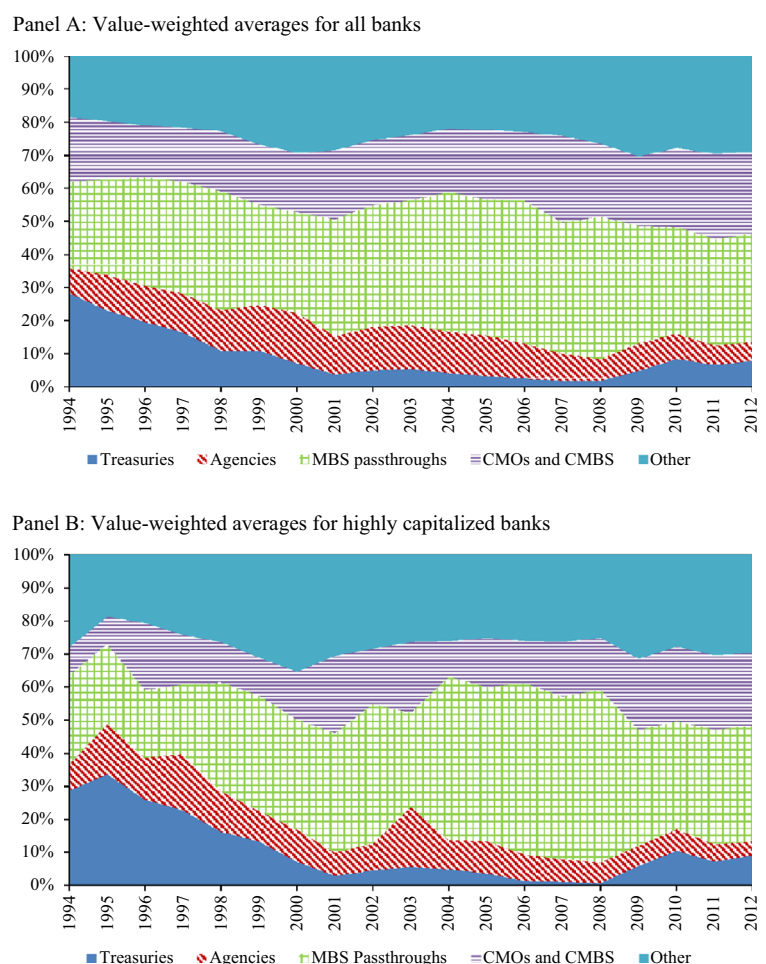

Fig. 2. Composition of bank securities portfolios, 1994-2012. This figure shows the composition of bank securities portfolios based on data from the Call Reports. We report bank holdings of various security types as a fraction of total bank investment securities (this excludes trading account assets). We restrict attention to banks with assets greater than $\$ 1$ billion. Panel A shows the value-weighted average securities portfolio for all banks. Panel B shows the securities portfolio of banks whose equity-to-assets ratio exceeds the industry median.

\subsection{Discussion}

Our synthesis of these stylized facts is that traditional banks are in the business of taking deposits and investing these deposits in fixed-income assets that have certain well-defined risk and liquidity attributes, but which can be either loans or securities. The information-intensive nature of traditional lending-in the Diamond (1984) delegated monitoring sense-while important in many cases, may not be the defining feature of banking. Rather, the defining feature may be that, whether they are information-intensive loans or relatively transparent securities, banks seek to invest in fixed-income assets that have some degree of price volatility and illiquidity, and so offer a higher return than very liquid and low-risk Treasury securities. In this sense, small business loans, asset-backed securities, and CMOs are on one side of the fence and Treasuries on the other.

Before proceeding, we should address a natural first reaction to this interpretation. Perhaps banks' propensity to invest in risky securities merely reflects the fact that they are taking advantage of the put option created by deposit insurance. In other words, the evidence we have assembled on the patterns of banks' securities holdings may merely reflect a moral hazard problem.

One way to address this hypothesis is to redo the analysis in Panel A of Fig. 2 restricting the sample to those banks with the highest levels of capital at any point in time-those whose equity-to-assets ratio is above the median. This is done in Panel B of Fig. 2. The basic patterns for highly capitalized banks in Panel B are very similar to those in Panel A for all banks. Given that these highly capitalized banks are less likely to impose losses on the deposit-insurance fund, we suspect that there is something deeper here than can be explained by a simple appeal to deposit-insurance-induced moral hazard.

\section{Model}

We develop a simple model in which banks and shadow banks compete as buyers of assets with different degrees of fundamental and liquidity risk. By raising expensive equity capital and gaining access to government deposit insurance, traditional banks obtain stable funding and are able to avoid asset fire sales. As a result, traditional banks can create moneylike claims by patiently investing in illiquid fixed-income assets, which have little long-run fundamental risk but are vulnerable to short-term price volatility. Shadow banks have less expensive funding but are vulnerable to runs and early asset liquidations. While their reliance on early exit means that shadow banks can create money-like claims by investing in assets with higher fundamental risk, these assets must be more liquid. Although we use the terms "traditional bank" and "shadow bank," we emphasize that the model speaks to intermediation strategies as opposed to specific legal institutions. 


\subsection{Setting}

The basic structure of the model is similar to Stein (2012). The model has three dates: $t=0,1$, and 2 . There are $N$ long-lived risky assets indexed by $i=1,2, \ldots, N$. Asset $i$ is available in a fixed supply of $Q_{i}$. For simplicity, we assume that the payoffs on these assets are perfectly correlated, and that assets only differ in the magnitudes of their payoffs in the bad state of the world. The individual assets in our model might correspond to corporate loans, mortgages, mortgage-backed securities (MBS), USTreasuries, or even equities.

The model features three types of actors: households, traditional banks, and shadow banks. Households do not directly own any of the risky assets. Instead, households invest in safe and risky claims issued by traditional and shadow banks, which in turn back these claims by holding the underlying risky assets. Intermediation is efficient here because households are willing to pay a premium for completely safe claims, and some form of intermediation is required to create safety-none of the primitive assets are themselves completely safe.

Households derive utility from both consumption and from monetary services. Our key assumption is that monetary services can only be derived from holding claims that are completely safe: if a claim has any risk it provides no monetary services. Outside of this demand for money-like claims, households are assumed to be risk-neutral with respect to fluctuations in their consumption. Thus, once a claim has any risk, the discount rate applied by households is fixed at a discretely higher level. This corresponds to the following household utility function from Stein (2012):

$$
U=C_{0}+\beta E\left[C_{2}\right]+\gamma M,
$$

where the notational convention is that a household has $M$ dollars of money-like claims if it has claims that are guaranteed to pay off an amount $M$ at $t=2$. The discount factor applied to all risky claims is thus $\beta \leq 1$, while the discount factor applied to safe money-like claims is $\beta+\gamma$, where $\gamma \geq 0$. The former follows from the observation that a household is indifferent between having $\beta$ units of time- 0 consumption and a risky claim that delivers one unit of time- 2 consumption in expectation. The latter follows from the fact that a household is indifferent between having $\beta+\gamma$ units of time- 0 consumption and a riskless claim that always delivers one unit of time- 2 consumption. Such a claim delivers $\beta$ units of utility from expected future consumption, along with an additional $\gamma$ units of utility from current monetary services.

When $\gamma>0$, the discount rate applied to safe money-like claims, $1 /(\beta+\gamma)$, is less than the discount rate applied to risky claims, $1 / \beta$. As in Stein (2012), Gennaioli, Shleifer, and Vishny (2013), and DeAngelo and Stulz (2015), the assumptions of the Modigliani-Miller (1958) theorem no longer hold, and the value of a risky asset may depend on the way it is financed using safe and risky claims. ${ }^{7}$

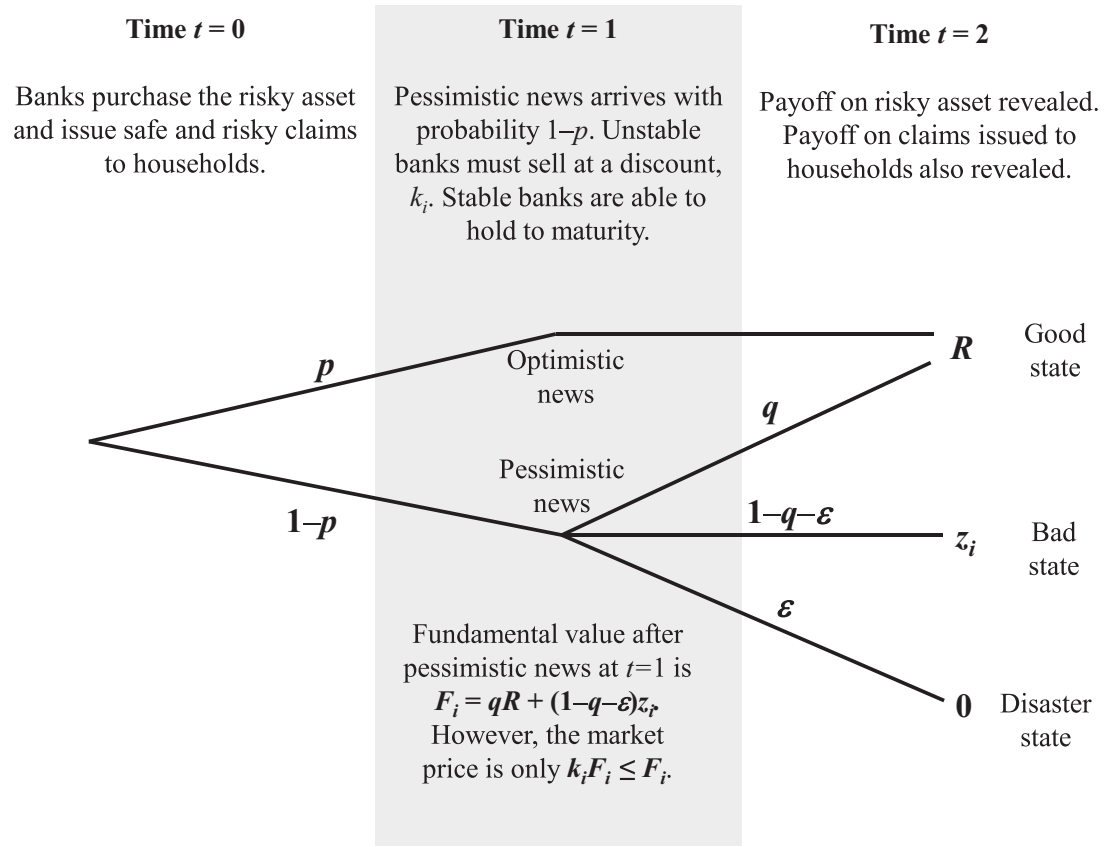

The timing of the model is as follows. Each risky asset $i$ pays $R$ at $t=2$ if the aggregate economic state of the world is good, but a lower amount $z_{i}<R$ if the aggregate economic state is bad. In addition, there is a very small probability of an economic disaster, in which case all risky assets pay zero. At time 1 , there is an interim news event about the future economic state. With probability $p$, the interim news is optimistic, which means that the aggregate state will be good at time

\footnotetext{
7 The assumption that all money-like claims are perfect substitutes is a simplification. Sunderam (2015) explores imperfect substitutability between different money-like claims.
} 
2 , and all assets will definitely pay $R$. With probability $(1-p)$, the news is pessimistic, which means that there is a subsequent probability $q$ of the good state in which all assets pay $R$, an $\varepsilon$ probability of the disaster state in which all assets pay zero, and a $(1-q-\varepsilon)$ probability of the bad state in which asset $i$ pays $z_{i}$. Thus, after pessimistic news at time 1 , the fundamental value of asset $i$ is $F_{i}=q R+(1-q-\varepsilon) z_{i}$.

The small probability of an economic disaster-the existence of tail risk-means that it is impossible for financial intermediaries to raise uninsured funding that is both stable and completely safe. In other words, intermediaries can only manufacture safe money-like claims by either relying on an early exit option, in which case the resulting funding is unstable, or on deposit insurance, in which case it is stable. Thus, our assumption that $\varepsilon>0$ is a simple way of capturing the robust fact that intermediaries who rely heavily on short-term, uninsured funding have always been vulnerable to run-like withdrawals when bad news arrives. Of course, if $\varepsilon=0$, it would be possible to raise stable funding without deposit insurance by simply limiting the amount of short-term claims to the worst-case payoff, $z_{i}$. All of our formal results carry through in the special case where $\varepsilon=0$. However, in this case, the quantity of stable deposits is limited by asset payoffs in the worst possible scenario.

Our central assumption deals with the difference between the fundamental value of asset $i$ at time 1 and its market value. We assume that, if there is pessimistic news at time 1 , the market value of asset $i$ is $k_{i} F_{i} \leq F_{i}$. When $k_{i}<1$, this market price reflects a fire-sale discount to fundamental value. The value of $k_{i}$ is endogenous and asset-specific and depends on the equilibrium quantity of asset $i$ that is liquidated at time 1 . We return to this feature momentarily.

Because our model only features aggregate risk and the payoffs on all assets are perfectly correlated, we are abstracting away from the need for diversification and risk management, which DeAngelo and Stulz (2015) see as central to intermediaries' ability to produce safe money-like claims. Our approach can be thought of as reflecting the idea that intermediaries have already done the best they can on these diversification and risk-management fronts, leaving only aggregate risk that cannot be diversified away or hedged.

\subsection{Intermediation strategies}

To examine the different ways that risky assets can be held and used as backing to create safe money-like claims, we consider two intermediation strategies: stable traditional banking and unstable shadow banking. At $t=0$, households can invest in either traditional or shadow bank deposits, both of which are completely safe and are valued at $\beta+\gamma$ per dollar paid at $t=2$. Alternatively, households can buy bank equity or shadow bank equity, both of which are risky and are valued at $\beta$ per dollar paid in expectation at $t=2$. Fraction $\mu_{i}$ of risky asset $i$ is purchased by shadow banks at $t=0$, and fraction $1-\mu_{i}$ is purchased by traditional banks. We examine how the equilibrium market shares of the traditional and shadow banking strategies vary as we change the properties of the asset in question.

\subsubsection{Traditional banking}

The traditional banking strategy uses deposit insurance and a hold-to-maturity investment approach to back safe money-like claims. A combination of risk-based capital requirements and fairly priced deposit insurance prevents traditional banks from exploiting the deposit insurance fund. Specifically, we assume that the government offers traditional banks actuarially fair deposit insurance that pays off in the disaster state. With a small probability of an economic disaster, traditional banks' hold-to-maturity strategy can only be used to create money-like claims if it is combined with deposit insurance. To protect taxpayers from further exposure, the government imposes a particular form of risk-based capital regulation: the bank is required to hold enough capital against any asset $i$ such that the deposit insurer never suffers losses in equilibrium in the bad (as opposed to the disaster) state. Since the bank plans to always hold the risky asset to maturity, the maximum amount of insured money-like claims that can be created using asset $i$ under this regulatory regime is $z_{i}$ which is the payoff in the bad state at time 2 . To satisfy the risk-based capital rule, the remainder of the asset purchase must be financed by risky equity capital, which is more expensive. Since the disaster state occurs with probability $(1-p) \varepsilon$, and deposit insurance pays $z_{i}$ in this state, the actuarially fair insurance premium discounted back to time 0 is $(1-p) \varepsilon \beta z_{i}$.

In the literal context of the model, capital regulation and the deposit insurance premium are the only costs to being a deposit-insured bank with stable funding, as opposed to a shadow bank with unstable funding. More broadly, however, one might interpret what we are calling the cost of equity capital as encompassing a variety of other costs that go along with being a traditional bank. These include the costs of other types of regulation as well as the bricks-and-mortar costs of setting up the sort of branch network that attracts sticky retail deposits.

The total value of claims the bank can issue at time 0 using the risky asset $i$ as backing is

$$
\begin{aligned}
& V_{i}^{B}=\overbrace{(\beta+\gamma) z_{i}}^{\text {Value of bank deposits }}-\overbrace{(1-p) \varepsilon \beta z_{i}}^{\text {Insurance premium }}+\overbrace{\beta(p+(1-p) q)\left(R-z_{i}\right)}^{\text {Value of bank equity }} \\
& \text { Money premium Expected cash flows } \\
& =\overbrace{\gamma z_{i}}^{p}+\beta \overbrace{\left[p R+(1-p) F_{i}\right]}
\end{aligned}
$$

where, again, $F_{i}=q R+(1-q-\varepsilon) z_{i}$ is the fundamental value of asset $i$ following pessimistic news at time 1 . In any equilibrium where banks hold asset $i$, banks' zero profit condition ensures that the market value of asset $i$ equals $V_{i}^{B}$. Because households 
are willing to pay a premium for absolutely safe claims, Eq. (3) shows that the total value of claims issued by banks exceeds the expected cash flows on the risky asset discounted at the risky rate: banks capture a money premium of $\gamma z_{i}$ because deposit insurance enables them to use the risky asset to back $z_{i}$ units of money-like claims.

\subsubsection{Shadow banking}

An alternative intermediation strategy for creating safe money-like claims is shadow banking. In the real world, what we are calling the shadow banking strategy often involves a chain of market-based transactions which can involve several distinct legal institutions.

Perhaps the simplest of these institutions is a money market fund (MMF) that invests in assets that are completely riskless, such as Treasury bills, and issues what are effectively deposits to households. Things become more complex when the asset ultimately backing the MMF deposits is not completely risk-free. To ensure that the MMF deposits are truly safe, some institution along the intermediation chain must contribute financing in the form of equity capital. At the end of the chain, households own a combination of money-like MMF deposits and highly levered equity.

This shadow banking strategy can be implemented using several alternative institutional arrangements, with more or fewer links in the chain. For example, a mortgage-backed security (MBS) may ultimately wind up backing money-like claims in several ways:

- A broker-dealer affiliate of a universal commercial bank finances the MBS using its own equity and a short-term repurchase agreement with a money market fund.

- A hedge fund acquires the MBS using its own equity and an overnight collateralized loan-a bilateral repo-from its prime broker. The prime broker, in turn, uses the same collateral to borrow from a money fund in the tri-party repo market, a process called "rehypothecation."

- A structured investment vehicle finances the MBS using its own equity and asset-backed commercial paper that is then sold to a money market fund or an institutional cash manager.

In each case, the common denominator is that there is a short-term claim at the end of the chain that is "flighty"-i.e., vulnerable to withdrawal in a bad state-because it is uninsured and protected only by the ability to exit early and liquidate the underlying collateral.

To fix ideas, it may be helpful to think of a simplified two-step chain consisting of a highly leveraged intermediary (HL) such as a broker-dealer along with a money market fund (MMF). The HL buys the risky asset and issues short-term repo against it, which is then held by the MMF. MMF deposits and HL equity are owned by households. The MMF does not have capital or access to government deposit insurance, so for its deposits to be riskless, its repo holdings must also be riskless. This is the case because if there is pessimistic news at time 1, the MMF seizes the repo collateral and sells it at the fire-sale price of $k_{i} F_{i}$. The maximum amount of safe money that can be created by a shadow bank is therefore $k_{i} F_{i}$. Unlike traditional bank depositors protected by deposit insurance and bank equity capital, an MMF that invests in repo cannot afford to sleep through time 1; the MMF's ability to pull the plug at this interim date is essential to keeping its claim safe. Uninsured shadow banking deposits are therefore an endogenous form of "hot" money: they are unstable rather than stable short-term funding. ${ }^{8}$

The total value of claims that the shadow banking system can create using the risky asset $i$ as a backing is then given by

$$
V_{i}^{S}\left(k_{i}\right)=\overbrace{(\gamma+\beta) k_{i} F_{i}}^{\text {Value of MMF deposits }}+\overbrace{\beta p\left(R-k_{i} F_{i}\right)}^{\text {Value of HL equity }}+\overbrace{\gamma k_{i} F_{i}}^{\text {Money premium }}+\overbrace{\beta\left[p R+(1-p) k_{i} F_{i}\right]}^{\text {Expected cash flows }} .
$$

In any equilibrium where shadow banks hold asset $i$, their zero profit condition ensures that the market value of asset $i$ must equal $V_{i}^{S}\left(k_{i}\right)$.

\subsection{Equilibrium}

We assume that shadow banks face a downward-sloping demand curve at time 1 , so the fire-sale price is a decreasing function of the amount of the asset that is liquidated. Formally, let $0 \leq \varphi_{i}$ be an exogenous parameter that indexes the illiquidity in the secondary market. We assume that $\partial k\left(\mu_{i}, \varphi_{i}\right) / \partial \mu_{i} \leq 0$, so demand is downward-sloping, and $\partial^{2} k\left(\mu_{i}, \varphi_{i}\right) / \partial \mu_{i} \partial \varphi_{i} \leq 0$, so more illiquid assets have steeper demand curves. Finally, as a normalization, we assume that

\footnotetext{
${ }^{8}$ Households only derive monetary services from claims that are guaranteed to be a safe store of value through time 2 . For shadow banks, safety requires early exit and hence a fire sale if the bad state occurs at time 1. However, ex post, the expected value is higher, albeit riskier, if the assets are held to maturity. So what ensures that the assets will be sold, thereby making good on the promise of safety? For some shadow banking chains, there may be coordination problems that lead to Diamond-Dybvig (1983) style runs which force the fire sale. However, even in the absence of coordination problems-e. g., if each MMF that invests in repo is protected by a segregated piece of collateral-commitment technologies can force the sale. For instance, MMFs are prohibited from holding the long-term assets that serve as collateral for repos, which commits them to fire-selling this collateral. While this may lead to inefficiencies ex post, it is optimal for MMFs ex ante, as it helps to assure their investors that their claims will be kept safe.
} 
$k\left(\mu_{i}, 0\right)=1$ for all $\mu_{i}$ : when $\varphi_{i}=0$, the asset is perfectly liquid and there is never any fire-sale discount. As shown in the Internet Appendix, a fire-sale discount of this form can be micro-founded as in Stein (2012). ${ }^{9}$

Since intermediaries are risk-neutral, and there are no benefits of diversification built into our model, intermediaries' willingness to hold asset $i$ is not impacted by their holdings of asset $j \neq i$. As a consequence, market equilibrium in any asset $i$ naturally decouples from that in asset $j \neq i$. An equilibrium for asset $i$ is a $\mu_{i}^{*}$ such that

$$
\begin{gathered}
V_{i}^{B}=V_{i}^{S}\left(k\left(\mu_{i}^{*}, \varphi_{i}\right)\right) \text { for } \mu_{i}^{*} \in(0,1) \\
V_{i}^{B}>V_{i}^{S}\left(k\left(0, \varphi_{i}\right)\right) \Rightarrow \mu_{i}^{*}=0 \\
V_{i}^{B}<V_{i}^{S}\left(k\left(1, \varphi_{i}\right)\right) \Rightarrow \mu_{i}^{*}=1 .
\end{gathered}
$$

The model admits both interior and corner solutions, depending on the asset-specific values of $z_{i}$ and $\varphi_{i}$. It is consistent with the possibility that some assets (e.g., highly illiquid loans) are held only by banks, some (e.g., Treasuries) are held predominantly by shadow banks, and some (e.g., MBS) are held in significant amounts by both intermediary types.

Formally, since $\partial V_{i}^{S}\left(k\left(\mu_{i}, \varphi_{i}\right)\right) / \partial \mu_{i}=\left(\partial V_{i}^{S} / \partial k\right) \times\left(\partial k / \partial \mu_{i}\right) \leq 0$, asset $i$ is held entirely by traditional banks when $V_{i}^{B}>V_{i}^{S}\left(k\left(0, \varphi_{i}\right)\right)$ and entirely by shadow banks when $V_{i}^{B}<V_{i}^{S}\left(k\left(1, \varphi_{i}\right)\right) .{ }^{10}$ Because shadow banks dominate traditional banks when there is no fire-sale discount (i.e., we always have $V_{i}^{B}<V_{i}^{S}(1)$ ), we only have a corner equilibrium where the asset is held entirely by traditional banks when $k\left(0, \varphi_{i}\right)<1$. By contrast, if $k\left(0, \varphi_{i}\right)=1$, then shadow banks must always hold some of the asset in equilibrium.

At an interior equilibrium in which both traditional and shadow banks hold the asset, the fire-sale discount $k_{i}$ is such that both traditional and shadow banks earn zero profits by buying the asset and issuing claims backed by it. Thus, at an interior equilibrium,

$$
\overbrace{(1-p) \beta \times\left[1-k\left(\mu_{i}^{*}, \varphi_{i}\right)\right] \times F_{i}}^{\text {Marginal benefit of stable funding: avoiding fire-sale liquidations }}=\overbrace{\gamma \times\left[k\left(\mu_{i}^{*}, \varphi_{i}\right) \times F_{i}-z_{i}\right]}^{\text {Marginal cost of stable funding:reduced money creation }} .
$$

Eq. (6) says that the mix between shadow banks and traditional banks must be such that the marginal benefit of stable bank funding equals the marginal cost of stable funding. Stable funding allows traditional banks to avoid the fire-sale liquidation discount if there is pessimistic news at time 1 . This benefit of traditional banks relative to shadow banks is captured by the left-hand-side of (6). However, precisely because investors can get out early, the market can generate a larger amount of unstable short-term funding than of stable funding using a given asset as backing. This cost of traditional banking relative to shadow banks is captured by the right-hand-side of (6). In summary, although traditional banks have more stable funding than shadow banks, this stability comes at a price: traditional banks create fewer money-like claims than shadow banks.

Solving Eq. (6), the equilibrium fire-sale discount is

$$
k_{i}^{*}=k\left(\mu_{i}^{*}, \varphi_{i}\right)=\frac{\gamma z_{i}+\beta(1-p) F_{i}}{\gamma F_{i}+\beta(1-p) F_{i}} .
$$

Finally, inverting the $k\left(\mu_{i}, \varphi_{i}\right)$ function, the equilibrium fraction of asset $i$ held by shadow banks is ${ }^{11}$

$$
\mu_{i}^{*}=k_{i}^{-1}\left(\frac{\gamma z_{i}+\beta(1-p) F_{i}}{\gamma F_{i}+\beta(1-p) F_{i}}\right) .
$$

To take a simple parametric example, assume $k\left(\mu_{i}, \varphi_{i}\right)=1-\varphi_{i} \times \mu_{i}$. In this case, we have $\mu_{i}^{*}=1$ if $\varphi_{i}=0-$ i.e., the asset is held exclusively by shadow banks if there is no fire-sale discount-and

$$
\mu_{i}^{*}=\min \left\{\frac{1-k_{i}^{*}}{\varphi_{i}}, 1\right\}=\min \left\{\frac{1}{\varphi_{i}} \frac{\gamma\left(F_{i}-z_{i}\right)}{\gamma F_{i}+\beta(1-p) F_{i}}, 1\right\},
$$

if $\varphi_{i}>0$, so that $\mu_{i}^{*} \rightarrow 0$ as $\varphi_{i} \rightarrow \infty$.

The equilibrium in our model is in the spirit of Miller (1977). While the aggregate mix of unstable $\left(\mu_{i}\right)$ versus stable funding $\left(1-\mu_{i}\right)$ for each asset $i$ is pinned down, in an interior equilibrium any small intermediary is indifferent between setting up shop as a bank or as a shadow bank. Relatedly, the model is silent about the boundaries of financial firms. In particular, a single institution-e.g., a universal-style bank with a broker-dealer affiliate-may wind up using both the traditional and shadow banking strategies.

Eq. (6) says that the equilibrium fire-sale discount is locally independent of asset illiquidity $\varphi_{i}$ at an interior equilibrium where both traditional and shadow banks hold the asset. In this region, a change in asset illiquidity impacts the mix of asset holders-an increase in illiquidity raises the market share of banks-but leaves the fire-sale discount unchanged. However, if

\footnotetext{
${ }^{9}$ Specifically, we assume that the risky asset is sold to a third type of intermediary (also owned by households) who has fixed resources and access to outside investment opportunities at $t=1$. Since these opportunities are characterized by diminishing returns, shadow banks must offer larger discounts to induce these intermediaries to purchase more assets, thereby forgoing increasingly productive outside opportunities. In this context, differences across assets in $\varphi_{i}$ reflect differences in the number of potential second-best holders of each asset-i.e., differences in asset specificity.

${ }^{10}$ Implicitly, by requiring $\mu \in[0,1]$, we are imposing a short-sale constraint for both traditional and shadow banks.

${ }^{11}$ Formally, the function $k_{i}^{-1}(x)$ is implicitly defined by $x=k\left(k_{i}^{-1}(x), \varphi_{i}\right)$.
} 
the assets are sufficiently liquid ( $\varphi_{i}$ is very low), the market share of traditional banks is eventually driven to zero, so the fire-sale discount is increasing in asset illiquidity for very low levels of $\varphi_{i}$.

\subsection{Comparative statics}

This simple model can be used to characterize the kinds of assets for which the traditional banking business model dominates. Two factors drive the tradeoff between traditional banks and shadow banks: the premium for money-like claims which is controlled by $\gamma$ and the strength of the fire-sale effect which is controlled by $\varphi_{i}$.

First, if $\gamma=0$ and $\partial k\left(\mu_{i}, \varphi_{i}\right) / \partial \mu_{i}<0$, we have $\mu_{i}^{*}=0$-the risky asset is held entirely by traditional banks. If there is no premium for money-like claims, shadow banking is dominated by traditional banking: unstable short-term debt forces inefficient liquidations and has no offsetting monetary benefits relative to stable deposit funding.

Conversely, if $\gamma>0$ and $\varphi_{i}=0$ so that $k\left(\mu_{i}, 0\right)=1$ for all $\mu_{i}$, then $\mu_{i}^{*}=1$-the asset is held entirely by shadow banks. The advantage of traditional banks' stable funding is that it enables them to ride out temporary departures of price from fundamental value without liquidating assets. Absent fire-sale risk, the price at time 1 always equals fundamental value and stable funding has no value; however, when $\gamma>0$, raising stable funding is always more costly than raising unstable funding.

The ideal asset for a traditional bank has very little fundamental cash-flow risk (i.e., $z_{i}$ is high so risk-based capital rules allow a bank to use it to back a lot of money-like deposits) but is exposed to meaningful interim re-pricing risk (i.e., $\varphi_{i}$ is high so fire-sale risk looms large for its shadow bank counterparts). When both $\gamma>0$ and $\varphi_{i}>0$, there is a meaningful tradeoff between the two intermediation structures, and equilibrium is interior.

For an interior equilibrium, we can ask how the equilibrium market shares of shadow banks $\left(\mu_{i}^{*}\right)$ and traditional banks $\left(1-\mu_{i}^{*}\right)$ vary with the exogenous model parameters. Differentiating Eq. (8), we immediately obtain the following comparative statics for the fraction of an asset held by traditional banks:

1. $\partial\left(1-\mu_{i}^{*}\right) / \partial \varphi_{i}>0$ : An increase in asset illiquidity increases the equilibrium share held by traditional banks. By assumption, an increase in asset illiquidity makes the demand curve for fire-sale liquidations at time 1 steeper. Although a change in asset illiquidity $\varphi_{i}$ has no effect on the equilibrium level of the fire-sale discount in (7), this change alters the mapping between the ownership mix and the fire-sale discount in (8). When $\varphi_{i}$ is high, the fire-sale discount is highly sensitive to the volume of forced sales by shadow banks, so traditional banks end up holding more of the asset in equilibrium.

2. $\partial\left(1-\mu_{i}^{*}\right) / \partial z_{i}>0$ : An increase in the worst-case cash flow $\boldsymbol{z}_{\boldsymbol{i}}$ increases the share of the risky asset $\boldsymbol{i}$ held by traditional banks in equilibrium. An increase in $z_{i}$ reduces the money-creation advantage of shadow banks relative to traditional banks and therefore needs to be compensated by a rise in $k_{i}^{*}$ which implies a rise in $1-\mu_{i}^{*}$ to restore equilibrium indifference between traditional and shadow banks. Since a higher $z_{i}$ reflects lower fundamental cash-flow risk, all else equal, traditional banks have a comparative advantage at holding assets with lower fundamental cash-flow risk.

Taken together, these two results suggest that traditional banks have a comparative advantage at holding illiquid fixedincome assets-i.e., assets that may experience significant temporary price dislocations but at the same time have only modest fundamental risk. Agency MBS might be a leading example of such an asset, because they are insured against default risk but are considerably less liquid than Treasury securities, and, for a given duration, have more price volatility, because there is significant variability in the MBS-Treasury spread.

The model also explains why banks are not well-suited to investing in equities-equities have too much fundamental downside risk. Because their value can fall very far over an extended period of time-i.e., because their $z_{i}$ is close to zeroequities cannot be efficiently used as backing for safe two-period claims. One reflection of this fact is that when banks do hold equities, they face prohibitively high regulatory capital requirements. ${ }^{12}$ In contrast, to the extent that they are highly liquid, equities do make suitable collateral for very short-term repo financing and can be used to back some amount of shadow bank money.

What happens as the underlying asset grows increasingly safe and liquid, itself becoming nearly money-like? In practice, this corresponds to asking who will hold short-term Treasury bills. In this limiting case, both the benefits and the costs in Eq. (6) vanish, so in our model the mix between traditional and shadow banks is indeterminate. However, this mix would be pinned down if we introduced a small overhead cost of traditional banking that scaled with assets under management, such as a cost of regulatory compliance. In this case, we would expect a nonbank vehicle such as a money market fund to hold the vast majority of T-bills.

In addition, we have the following comparative statics which impact all assets:

3. $\partial\left(1-\mu_{i}^{*}\right) / \partial \gamma<0$ : An increase in the premium on safe money-like claims lowers traditional banks' equilibrium market share of all risky assets. When the premium associated with safe money-like claims is higher, the fire-sale discount must rise to maintain equilibrium (i.e., $k_{i}^{*}$ must fall), so the fraction of risky assets held by shadow banks, $\mu_{i}^{*}$, must rise.

4. $\partial\left(1-\mu_{i}^{*}\right) / \partial p<0$ : An increase in the probability of good news at time 1 lowers the share of all risky assets held by traditional banks. When the interim good state is more likely, a larger fire-sale discount (lower $\left.k_{i}^{*}\right)$ is needed to restore

\footnotetext{
${ }^{12}$ US banks are currently required to finance any common stock holdings with at least $24 \%$ of loss-absorbing capital. The corresponding capital requirements for commercial loans and residential mortgages are $8 \%$ and $4 \%$, respectively.
} 
indifference, and the market share of shadow banks, $\mu_{i}^{*}$, must rise in equilibrium. Intuitively, the bank's stable funding structure functions as a costly form of insurance against fire-sale risk; this insurance naturally becomes less valuable when a fire sale is less likely (i.e., when $p$ rises).

Comparative static \#3 suggests that an increase in the demand for safe money-like assets should trigger a migration of intermediation from traditional to shadow banking. Indeed, some observers have argued that such an increase in money demand played a role in fueling the rapid growth of shadow banking prior to the recent financial crisis. Comparative static \#4 suggests that intermediation activity tends to migrate from traditional banks towards shadow banks during economic expansions when $p$ is high. In this way, the model explains why traditional banks lost significant market share to shadow banks during the run-up to the recent financial crisis.

\subsection{Model extensions}

We have deliberately kept the model quite spare. First, we have assumed that the demand for safe money-like claims is infinitely elastic and hence never satiated (i.e., households have linear utility over money-like asset holdings). In a more general model, the demand for money-like claims would be downward-sloping (corresponding to concave utility over safe money-like claims), so the liquidity premium would decline with the total quantity of money-like claims provided by intermediaries. We can extend our model to allow the liquidity premium to be determined this way in equilibrium. Holding fixed the equilibrium money premium, our key results on the cross-section of risky assets still obtain: traditional banks hold a larger share of more illiquid assets and of assets with less fundamental risk.

We have also implicitly assumed that, to the extent it is technologically feasible, intermediaries use all risky assets as fodder for backing money-like claims. One might extend the model so that some risky assets are not used to back moneylike claims and instead are held directly by households in equilibrium. For some risky assets to not be used as fodder for backing safe money-like claims, we would need to add an overhead cost of traditional banking as in DeAngelo and Stulz (2015). Going further, we could add assets like Treasury bills that are perfectly safe even in the absence of any tranching by financial intermediaries. As explored in Greenwood, Hanson, and Stein (2015) and Krishnamurthy and Vissing-Jorgensen (2015), with downward-sloping demand for money-like assets, changes in the supply of T-bills would depress the premium on money-like claims, reducing the incentive of shadow banks and traditional banks to bear the fire-sale and overhead costs incurred in intermediation.

\subsection{Discussion}

While banks' asset holdings are the most noteworthy complement to their stable funding structures, our model may help shed light on other aspects of commercial banks' modern business model. Consider, for example, the bricks-and-mortar costs associated with bank deposit-taking. We have estimated these costs to be quite high, averaging on the order of 1.30 percent of deposits over the period from 1984 to 2012. These costs ultimately represent a choice-banks could always choose to offer their customers fewer and less attractive branch locations, fewer opportunities for interacting with a human teller, and so forth. One view is that these amenities are a separable flow of services to depositors, conceptually analogous to paying more interest. However, an interesting alternative is that they represent a deliberate effort to build loyalty by creating a form of switching costs. Investing in such switching costs and thereby increasing deposit stickiness is complementary to an overall business model based on the premise of having stable funding. By contrast, a money market fund complex-which also takes deposits, but which invests exclusively in short-term assets-has less reason to care about deposit stickiness and hence less incentive to spend on a branch network.

The model may also have something to say about the contrasting accounting practices of commercial banks and the institutions that play a crucial role in the shadow banking system: money market funds, broker-dealers, and hedge funds. These market-based institutions typically lack access to stable short-term funding and operate on a mark-to-market accounting basis. Even if a decline in security prices is temporary and driven by nonfundamental factors, it impacts their accounting earnings. In contrast, accounting conventions for banks shield their earnings from transitory changes in the unrealized market value of loans or securities. These "temporary impairments" flow through another liability account called "accumulated other comprehensive income" and only impact reported earnings if the gains or losses are realized by selling the security. If movements in asset prices are driven entirely by fundamental news about future cash flows, then commercial banks' accounting practices seem perplexing. However, to the extent that asset price movements are driven by nonfundamental shocks which the banks' stable funding structure enables them to ride out, these accounting practices may be sensible (see also Cochrane, 2011).

\section{Commercial banks in historical perspective}

Our model sheds light on the significant shifts in commercial banks' business model over the last 150 years. Our central prediction is the complementarity between the three features of modern commercial banking: deposit insurance, stable funding, and investment in long-term fixed-income assets that are nonetheless subject to price fluctuations. It is therefore natural to ask what commercial banking in the US looked like before the introduction of deposit insurance. The model 
predicts, not surprisingly, that bank funding was less stable. Perhaps more surprisingly, the model also predicts that bank assets prior to deposit insurance would have needed to be shorter-term and easier to liquidate without losses. The evidence presented below is strikingly consistent with this prediction. Indeed, during the late $19^{\text {th }}$ and early $20^{\text {th }}$ centuries, US commercial banks employed a business model similar to the strategy we have called "shadow banking."

During the National Banking Era from 1865-1914, nationally chartered banks were financed with demand deposits (68\% on average during this period), national bank notes (8\%), and equity (24\%). While commercial banks were heavily reliant on deposit funding just as they are today, they held very different assets. ${ }^{13}$ Without deposit insurance, the banking system regularly faced mass depositor withdrawals, and the prevailing philosophy-enshrined in both the National Banking Act of 1864 and the Federal Reserve Act of 1913-“emphasized the importance of keeping bank assets liquid by (largely) confining the use of bank funds to short-term loans" (Moulton, 1918, p. 638).

To begin, national banks held far more cash and interbank deposits than they do today. On average, cash items accounted for $27 \%$ of assets from 1865 to 1914 versus less than $4 \%$ for commercial banks prior to the 2008-2009 crisis. $^{14}$ Banks' loan portfolios (averaging 55\% of assets) were concentrated in short-term loans to finance working capital or short-term collateralized loans. Finally, from 1865 to 1914, securities comprised 17\% of bank assets. Banks'securities were concentrated in Treasuries, state and local bonds, and railroad bonds-all "of high grade as to both security and marketability" (Moulton, 1918, p. 711).

Banks primarily made short-term "commercial loans" to finance working capital that were "automatically selfliquidating," while avoiding illiquid longer term "industrial loans” to finance permanent capital (Myers, 1931; White, 1998). The Comptroller of the Currency bluntly summarized this view in 1876: "Banks are not loan offices. It is not part of their business to furnish their customers with capital" (Bolles, 1890, p. 70). Prior to 1913, national banks were prohibited from making real estate loans because "deposits payable on demand should not be invested in real estate financing" Pollock (1993). ${ }^{15}$ The principal lending instruments included loans secured by short-term trade receivables or "trade acceptances" (similar to factoring), short-term unsecured working capital loans or "commercial paper," overnight margin loans collateralized by stocks and bonds or "call loans," and other short-term, collateralized loans. Banks typically rolled over these short-term loans in normal times (Moulton, 1918). ${ }^{16}$

In $1896,20 \%$ of all loans by national banks were due on demand, primarily in the form of call loans backed by stocks and bonds (Statistical Abstracts of the US, 1896, Table 28). Trade acceptances and commercial paper were also quite short-term. James (1978) argues that the maturities of these loans typically ranged from 30 to 90 days, with an average maturity of 60 days and an upper bound of one year. Furthermore, the banks in major cities, which faced the greatest risk of withdrawal by depositors, tended to hold shorter-term paper than country banks whose deposits were somewhat more sticky (Myers, 1931). ${ }^{17}$ Commercial banks' maturity mismatch and liquidity mismatch were far more limited than they would become after the introduction of deposit insurance in 1933 (White, 1998).

Furthermore, there were telling differences between national banks, which were largely financed with demand deposits, and state banks, which were more reliant on savings and time deposits. ${ }^{18}$ While state banks made short-term commercial loans, they made some longer-term real estate loans as well. Under state regulations, the amount of real estate loans was tied to amount of time deposits or equity capital (White, 1998). According to Pollock (1993), "real estate loans, which represent, by definition, illiquid underlying assets, should be explicitly tied to less liquid bank liabilities." Finally, "mutual savings banks" specialized in longer-term real estate loans, but were entirely financed by equity and savings deposits subject to withdrawal limitations.

During the recurring financial crises of this era-there were major banking panics in 1873, 1884, 1893, 1890, 1896, 1907, and 1914 (Calomiris and Gorton, 1991)-banks faced significant withdrawals from individual depositors. For instance, during the severe panics of 1873 and 1893, deposits at national banks shrank by $16 \%$ and $17 \%$, respectively, over the course of several months. These withdrawals were met, in part, by drawing down excess reserves, but also by calling in loans due on demand and declining to roll over maturing time loans (Sprague, 1910; Myers, 1931; Friedman and Schwartz, 1963). In 1873 and 1893, total loans extended by national banks shrank by 17\% and 15\%, respectively. Consistent with an inward shift in loan supply, crises were typically marked by large spikes in interest rates-call loan rates often rose by ten or more percentage points with commercial paper rates rising by three or more percentage

\footnotetext{
${ }^{13}$ National bank notes-a form of legal paper money backed by banks' holdings of certain US Treasury securities-were a major liability item for national banks during the beginning of the era.

${ }^{14}$ Legal reserve requirements were far higher-reserve requirements on all deposits were $15 \%$ for country banks and $25 \%$ for city banks. Today, reserve requirements are $10 \%$ on transaction accounts, which account for only $12 \%$ of total deposits. However, according to Myers (1931), reserve requirements were not binding: most state-chartered banks had voluntarily held similar levels of reserves prior to the passage of the National Banking Act.

15 The Federal Reserve Act of 1913 loosened this restriction somewhat, allowing national banks to make loans secured by farmland, provided that they were limited to a $50 \%$ loan-to-value ratio and maturities of less than five years. However, real estate loans were limited to the greater of $25 \%$ of a bank's capital or 33\% of its time deposits. In 1916, national banks were permitted to make one-year loans secured by urban real estate. These limits on real estate lending were gradually relaxed and were eliminated with the Garn-St. German Act of 1982.

${ }^{16}$ To ensure they were not financing permanent capital, banks subjected borrowers to an annual "clean up," requiring them to briefly repay all debts, perhaps by borrowing from another bank (Moulton, 1918; White, 1998).

${ }^{17}$ For instance, while loans due on demand were $12 \%$ of the loan portfolios of country banks, they represented $35 \%$ of loans for banks in New York City. (Statistical Abstracts of the US, 1896, Table 28).

${ }^{18}$ In part, this was because national banks faced the same reserve requirement on all deposit types. By contrast, state banks typically faced lower reserve requirements for time and savings deposits (White, 1998).
} 
points (Sprague, 1910; Champ, 2007). ${ }^{19}$ Because country banks typically drew down balances they held at city banks, these loan "liquidations" were often most pronounced at city banks, particularly New York City banks. In the Panic of 1873, loans extended by New York City banks shrank by $41 \%$.

These loan liquidations were similar to the fire-sale mechanism in our paper. The closest analog lies in the call loans secured by stocks and bonds. The forced sales triggered by reductions in margin lending were widely thought to have exacerbated the declines in stock and bond prices in many of the era's financial crises, including the 1929 crash (Sprague, 1910; Moen and Tallman, 1990; Galbraith, 1954; Meltzer, 2002). The inevitable post-crisis decline in real activity was often attributed, in part, to the forced liquidation of commercial loans used to finance working capital. Moulton (1918, pp. 719720) recognizes the costs of these liquidations, writing:

"Loans to [meat]packers had always been considered extremely liquid, and when, in 1907, the Chicago banks were desirous of replenishing their reserves they asked Mr. Armour to liquidate his loans ... Now it is true that any particular packinghouse note is liquid. It will be paid whenever a bank desires-even before maturity. But such payments are largely effected through a shifting process, for the loan from bank $A$ that is paid promptly reappears as a loan from bank $B$... But while any particular [meat]packing-house loan is thus liquid, it is an entirely different matter when it comes to liquidating all of them at once. Banks ... furnish permanent working capital to the [meat]packers, and it would be impossible for the packinghouses to liquidate all their loans without disrupting the entire live-stock industry."

Importantly, the ubiquity of short-term bank loans during this era does not appear to stem from a lack of demand for long-term credit. According to Myers (1931, p. 45), "attempts on the part of a bank to confine its loans to short-term paper were often bitterly resented by the community." To the extent that state governments or corporations (e.g., railroads) needed access to long-term financing, they had to sell stocks or bonds (Moulton, 1918; White, 1998). Stocks and bonds were often bought by foreign investors (Myers, 1931) or domestically by life insurers who had long-term sticky liabilities (White, 1998). Interestingly, there was a thriving original issue high-yield bond market in the first several decades of the 20th century, many decades before Michael Milken (Greenwood and Hanson, 2013). A plausible hypothesis is that the junk bond market flourished precisely because banks were unable to supply longer-term loans to commercial borrowers.

After the introduction of federal deposit insurance in 1933, one of the major policy goals was to encourage banks to make longer-term and effectively more illiquid loans. Specifically, bank regulators were asked not to "criticize" long-term commercial loans and national banks were given much greater latitude to make real estate loans starting in 1934 (White, 1998). It appears that policymakers were concerned that the kind of short-term bank lending that dominated prior to the introduction of deposit insurance had imposed a sort of credit-crunch externality on the real economy, making economywide downturns more severe because firms were forced to prematurely liquidate real projects to pay off short-term bank loans.

In summary, in the late 19th and early 20th centuries, the deposits of US commercial banks were kept safe and liquid by largely restricting bank assets to cash and very short-term loans-i.e., by limiting the liquidity mismatch between assets and liabilities. What we have termed the "traditional banking" strategy-a buy-and-hold approach that uses long-term, illiquid assets to back short-term deposits-is best seen as a mid-20th century development that was made possible by the introduction of a reliable lender of last resort and federal deposit insurance.

\section{Contemporary evidence}

In this section, we provide some contemporary aggregate evidence bearing on the model's predictions. We first describe how we take the model to the data, then our measurement approach, and finally, the results of some simple cross-sectional regressions suggested by the model.

\subsection{Taking the model to the data}

5.1.1. The cross-section of asset classes

A key testable implication of our model is that, all else equal, traditional banks should hold a higher market share in more illiquid assets: $\partial\left(1-\mu_{i}^{*}\right) / \partial \varphi_{i}>0$.

Prediction 1. Looking across assets and holding constant fundamental asset risk, banks should have a larger market share in asset classes that are more illiquid.

Our model features just two intermediary types: traditional banks with stable funding and shadow banks with unstable funding. In reality, there are many intermediary types with a range of funding stability. Generalizing our theory, we would expect intermediaries with more stable funding to hold more illiquid assets with high fire-sale risk.

19 The behavior of commercial bank deposits and lending during crisis periods in the late 19th and early 20 th centuries stands in sharp contrast to the behavior of today's insured commercial banks. In more recent times, insured bank deposits have often benefitted from safe-haven inflows during crisis periods. Furthermore, there is often an expansion in outstanding bank loans during periods of financial strain as existing loan commitments are drawn down (Kashyap, Rajan, and Stein, 2002; Gatev and Strahan, 2006; Ivashina and Scharfstein, 2010). 
Prediction 2. Looking across assets and holding constant fundamental asset risk, more illiquid asset classes should be held by intermediary types with greater funding stability.

\subsubsection{The cross-section of intermediary types}

Since our theory has predictions for the cross-section of asset types, it naturally generates related predictions for the cross-section of intermediary types. Specifically, the portfolio share of shadow banks in asset $i$ is

$$
w_{i}^{S *}=\frac{\mu_{i}^{*} Q_{i}}{\sum_{k=1}^{N} \mu_{k}^{*} Q_{k}},
$$

and the portfolio share of traditional banks in asset $i$ is

$$
w_{i}^{B *}=\frac{\left(1-\mu_{i}^{*}\right) Q_{i}}{\sum_{k=1}^{N}\left(1-\mu_{k}^{*}\right) Q_{k}} .
$$

It follows trivially from the comparative statics derived above that $\partial w_{i}^{S *} / \partial \varphi_{i}<0, \quad \partial w_{i}^{S *} / \partial z_{i}<0, \partial w_{i}^{B *} / \partial \varphi_{i}>0$, and $\partial w_{i}^{B *} / \partial z_{i}>0$. In other words, shadow bank portfolios are tilted towards assets that are more liquid or have more fundamental downside-risk, whereas traditional bank portfolios are tilted towards assets that are more illiquid and have less fundamental downside-risk.

The average illiquidity of assets held by shadow banks is

$$
\Phi^{S *}=\sum_{i=1}^{N} w_{i}^{S *} \varphi_{i}
$$

and the average illiquidity of assets held by commercial banks is

$$
\Phi^{B *}=\sum_{i=1}^{N} w_{i}^{B *} \varphi_{i}
$$

If all assets have the same $z_{i}$, in equilibrium we have

$$
\Phi^{B *}>\Phi^{S *}
$$

That is, the asset portfolios of traditional banks should be more illiquid than those of shadow banks.

Prediction 3. The asset portfolios of commercial banks are more illiquid than the asset portfolios of shadow banks, controlling for fundamental risk.

As above, we can generalize this to obtain a prediction that we can apply to the broader cross-section of intermediary types, including insurers and finance companies.

Prediction 4. Comparing across intermediaries, those with more stable funding should have asset portfolios that are more illiquid, controlling for fundamental risk.

\subsection{Measurement}

Let $j$ index intermediary types, and let $i$ index instrument types-i.e., different types of assets or liabilities. Let $I L L I Q U I D_{i} \in[0,1]$ measure the illiquidity of asset type $i$. For instance, US Treasuries should have $I L L I Q U I D_{i}=0$, and $\operatorname{small}$ business loans might have $\operatorname{ILLIQUID}_{i}=1$. Similarly, let MATURITY $Y_{i} \in[0,1]$ measure the contractual maturity length of liability type $i$ and $\operatorname{STICKY}_{i} \in[0,1]$ measure the stickiness of liability type $i$. Stickiness is the opposite of runniness, which is the tendency for liability holders to withdraw funds following an adverse shock. For instance, short-term commercial paper might have $S T I C K Y_{i}=0$, while long-term (nonredeemable) equity would have $S T I C K Y_{i}=1$.

Let $A_{j i}$ and $L_{j i}$ denote intermediary $j$ 's assets and liabilities of instrument type $i$ and let $A_{j}=\sum_{i} A_{j i}=\sum_{i} L_{j i}$ denote the total assets of intermediary type $j$. Then the Asset Illiquidity Index for intermediary type $j$ is defined as the weighted average illiquidity of its asset holdings

$$
A \_I L L I Q U I D_{j}=\frac{\sum_{i} A_{j i} \times I L L I Q U I D_{i}}{A_{j}} .
$$

The Liability Maturity Index for intermediary type $j$ is the weighted average contractual maturity of its liabilities

$$
L_{-} \text {MATURITY }_{j}=\frac{\sum_{i} L_{i j} \times M A T U R I T Y_{i}}{A_{j}} .
$$

Finally, the Liability Stickiness Index for intermediary type $j$ is the weighted average stickiness of its liabilities

$$
L_{-} \operatorname{STICKY} Y_{j}=\frac{\sum_{i} L_{j i} \times \operatorname{STICK} Y_{i}}{A_{j}} .
$$

Our measurement approach is in the spirit of Brunnermeier, Gorton, and Krishnamurthy (2014), who suggest constructing a liquidity mismatch index-the difference between asset illiquidity and funding liquidity-for different 


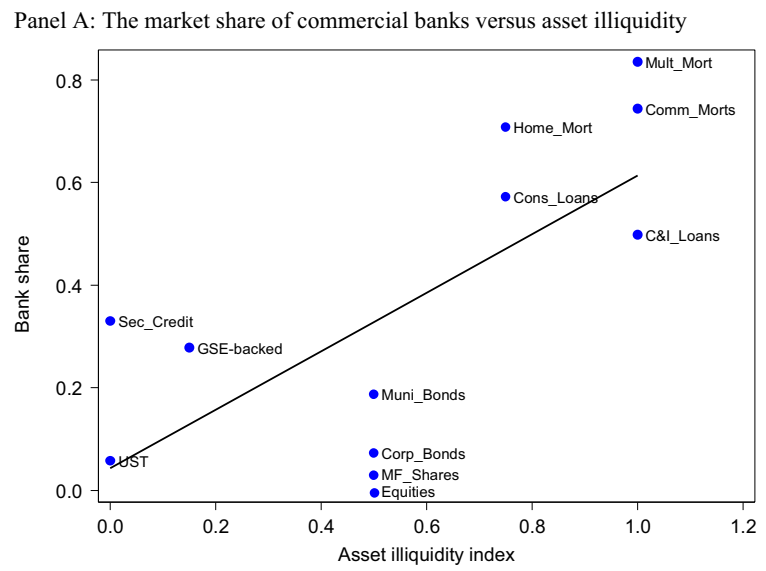

Panel B: The average liability stickiness of asset holders versus asset illiquidity

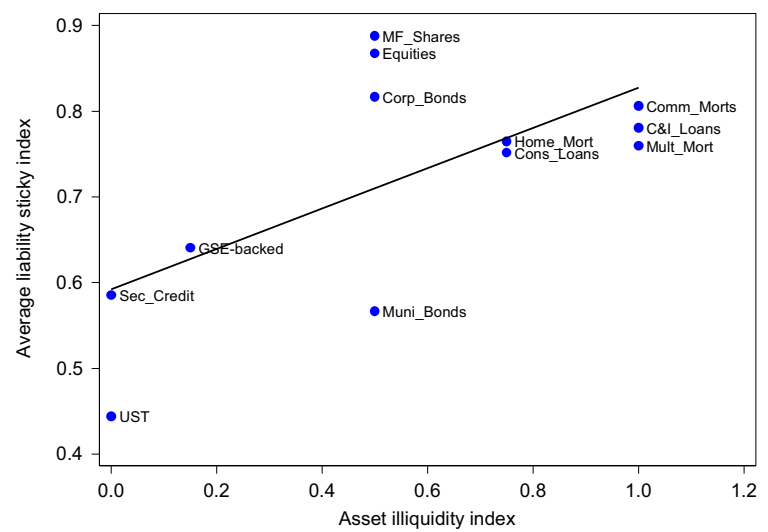

Fig. 3. The cross-section of asset classes. Panel A plots BANK SHR $i$ versus ILLIQUID $D_{i}$ for major financial asset classes. Panel B plots $A V$ STICKY $Y_{i}$ versus $I_{L L I Q U I D}$. The figures are based on data from the Financial Accounts of the United States as of 2012Q4 and information contained in BCBS (2010 and 2013). See the Internet Appendix for further details.

financial intermediaries. This approach is implemented in Bai, Krishnamurthy, and Weymuller (2015) for bank holding companies.

We assemble data on the assets and liabilities of various types of financial intermediaries using the Federal Reserve's Financial Accounts of the United States (formerly the Flow of Funds Accounts). We examine data on commercial banks, property and casualty ( $P \& C$ ) insurers, life insurers, money market funds (MMFs), government sponsored enterprises (GSEs), finance companies, real estate investment trusts (REITs), and security broker-dealers. We use data on intermediary balance sheets as of 2012Q4. However, the findings of our analysis do not depend significantly on when we look at the data.

In an effort to avoid subjective judgments, wherever possible we assign numerical values for ILLIQUID ${ }_{j}$, MATURITY, and $S T I C K Y_{j}$ based on the bank liquidity requirements recently put forth under Basel III Accord. (To be clear, these new liquidity requirements are distinct from the more familiar risk-based capital requirements.) Specifically, for each instrument type, we attempt to choose values of these parameters based on the proposed calibration of Basel III's Net Stable Funding Requirement (NSFR) in Basel Committee on Banking Supervision (2010) and the final calibration of the Liquidity Coverage Ratio (LCR) in Basel Committee on Banking Supervision (2013), hereafter BCBS (2010 and 2013). However, we do need to apply some judgment in mapping the instrument types considered by Basel III to our aggregated Financial Accounts data. We also need to assign values for liability types issued by nonbanks that are not considered by BCBS. As we detail in the Internet Appendix, we have made every attempt to do so in the spirit of BCBS (2010 and 2013) and consistent with empirical evidence. The most important auxiliary assumption we make is that the policy liabilities of life insurers are quite sticky, whereas those of $P \& C$ insurers are less sticky. ${ }^{20}$

Consider first our ILLIQUID index for assets. We associate ILLIQUID with the parameter $\varphi_{i}$ in the model. We assign $I L L I Q U I D=0$ for US Treasuries, ILLIQUID $=0.15$ for GSE-backed MBS, ILLIQUID $=0.5$ for corporate equities, ILLIQUID $=0.75$ for

\footnotetext{
${ }^{20}$ See Bai, Krishnamurthy, and Weymuller (2013) for a similar, albeit more sophisticated, approach that requires more granular balance sheet data than is available in the Financial Accounts. Specifically, they use measures of asset illiquidity based on repo haircuts.
} 


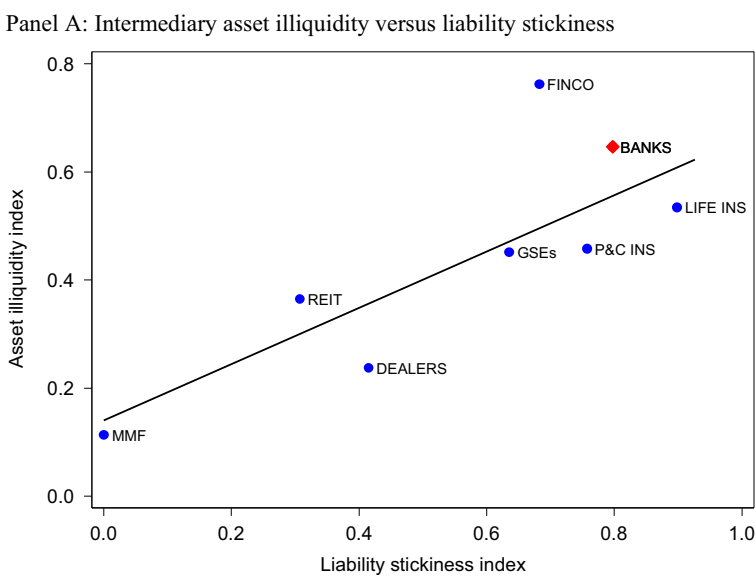

Panel B: Intermediary asset illiquidity versus liability contractual maturity

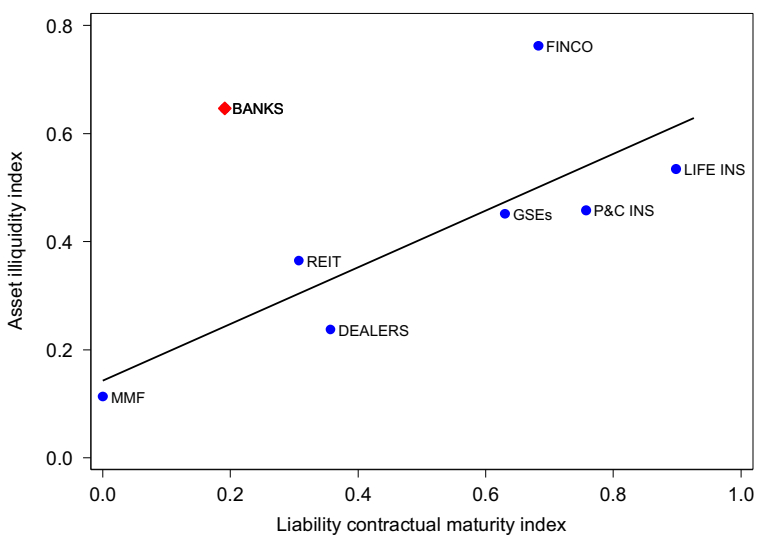

Fig. 4. The cross-section of intermediary types. Panel A plots $A_{-} I L L I Q U I D_{j}$ versus $L_{-} S T I C K Y_{j}$ for different intermediary types. Panel B plots $A \_I L L I Q U I D_{j}$ versus $L_{-}$MATURITY ${ }_{j}$. The figures are based on data from the Financial Accounts of the United States as of $2012 \mathrm{Q} 4$ and information contained in BCBS (2010 and 2013). See the Internet Appendix for further details.

consumer debt and home mortgages, and ILLIQUID $=1$ for unsecured commercial and industrial (C\&I) and secured commercial real estate (CRE) loans.

Next, consider our STICKY and MATURITY indices for liabilities. Starting with bank deposits, we assign STICKY=0.7 and MATURITY $=0.1$ for wholesale bank deposits, STICKY $=0.8$ and MATURITY $=0$ for retail time and savings deposits, and STICKY $=0.9$ and MATURITY $=0$ for transactions deposits. Turning to nondeposit liabilities, we assign STICKY=0.6 and MATURITY $=0.6$ for corporate bonds and STICKY $=0$ and MATURITY $=0$ for nondeposit, short-term funding. For insurance policy liabilities, we assume STICKY $=$ MATURITY $=0.9$ for life policies and STICKY $=$ MATURITY $=0.6$ for P\&C policies.

\subsection{Empirical tests}

\subsubsection{The cross-section of asset classes}

Prediction 1 says that traditional banks should hold a higher market share in more illiquid assets. A simple way to assess this prediction is to compute banks' market share for each asset type

$$
\text { BANK_SHR }{ }_{i}=A_{b a n k, i} / \sum_{j} A_{j i} \text {. }
$$

In other words, for each asset type, we compute banks' share of the total amount of assets held by financial intermediaries. ${ }^{21}$ Since BANK_SHR $R_{i}$ corresponds precisely to $\left(1-\mu_{i}\right)$ in the model, and ILLIQUID $D_{i}$ corresponds to $\varphi_{i}$, we should see a strong positive relationship between $B A N K_{-} S H R_{i}$ on $I L L I Q U I D_{i}$ in the cross-section of asset types.

Panel A of Fig. 3 shows the result. The estimated regression is

$$
\text { BANK_SHR } i=0.04+\underset{(t=3.47)}{0.57} \times I L L I Q U I D_{i}, R^{2}=0.47 .
$$

\footnotetext{
${ }^{21}$ Specifically, we compute the share of assets held by the Financial Business sector in Table L.107 of the Financial Accounts that is attributable to USChartered Depository Institutions in Table L.110.
} 
As predicted, there is a strong positive relationship between asset illiquidity and banks' market share. Of course, this is just a descriptive cross-sectional regression with 12 observations. It is also a univariate regression, whereas our theory suggests a bivariate relationship: banks' market share of a given asset should depend on both the asset's illiquidity and its fundamental safety. If the two characteristics are correlated-as they likely are-then (19) suffers from an omitted variable bias. To address this concern, we run a multivariate regression of banks' market share on asset illiquidity and fundamental safety, expecting positive coefficients on both. To run this multivariate regression, we create a new variable called FUNDSAFE, which we set equal to negative one times the risk-weight under current US risk-based capital regulations. ${ }^{22}$ While this is solely meant to be illustrative, this approach yields

$$
\text { BANK_SHR } R_{i}=0.14+\underset{(t=4.87)}{0.68} \times I L L I Q U I D_{i}+\underset{(t=5.41)}{0.16} \times \text { FUNDSAFE }_{i}, R^{2}=0.73 .
$$

The coefficient on $\operatorname{ILLIQUID}_{i}$ is larger in the multivariate regression and the $R^{2}$ rises considerably. Another crude way to address this omitted variable bias is to run a univariate regression of banks' market share on illiquidity alone, dropping those asset classes with significantly greater fundamental cash-flow risk. For instance, if we drop equity-like instruments (corporate equities and mutual fund shares), the $R^{2}$ in the univariate regression rises from 0.47 to 0.59 .

Turning to Prediction 2, other intermediaries besides traditional banks may also have stable funding and thus may also have a comparative advantage at holding illiquid assets. To capture this, we compute the average funding stability of holders of a given asset as

$$
A V \_S T I C K Y_{i}=\frac{\sum_{j} A_{j i} \times L_{-} S T I C K Y_{j}}{\sum_{j} A_{j i}} .
$$

Because $A V \_S T I C K Y_{i}$ is a generalized version of $\left(1-\mu_{i}\right)$ in the model, and ILLIQUID $i$ corresponds to $\varphi_{i}$, Prediction 2 suggests that we should observe a strong positive relationship between the two in the cross-section. This is shown in Panel B of Fig. 3 ,

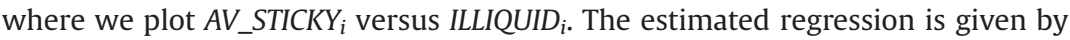

$$
A V_{-} S T I C K Y_{i}=0.59+\underset{(t=3.40)}{0.23} \times I L L I Q U I D_{i}, R^{2}=0.41 .
$$

Again, we see a strong positive relationship. The $R^{2}$ of this regression rises from 0.41 to 0.64 if we exclude corporate equities and mutual fund shares.

Fig. 3 confirms the core message of our model. Banks hold virtually no Treasuries despite their extreme safety. Treasuries are not exposed to interim fire-sale risk, so they are not profitable enough for banks. By contrast, banks are significant holders of GSE-backed MBS. These securities have limited downside-risk, so banks can use them to back nearly as much money-like short-term debt as a shadow bank. At the same time, GSE-backed MBS are more exposed to fire-sale risk than Treasuries, which makes them more attractive to traditional banks.

Fig. 3 also shows that banks have a dominant market share in illiquid home mortgage loans, holding approximately 76\% of unsecuritized whole loans. Banks are also the largest holders of illiquid commercial and multi-family home mortgages. Going beyond Fig. 3, even within the category of home mortgages, banks tend to hold less "plain-vanilla" products, for which liquidation costs are likely higher. Specifically, banks are the dominant holders of second-lien home equity loans and other mortgage products falling outside of the conventional mortgage markets supported by the GSEs. ${ }^{23}$

Finally, Fig. 3 shows that banks remain significant holders of unsecured loans to firms, holding $48 \%$ of all C\&I loans. As with home mortgages, when one looks within the category of C\&I loans, banks seem to specialize in those that are the most illiquid. For instance, banks have been steadily losing market share in the market for C\&I loans to large firms, which has become increasingly liquid in recent decades. At the same time, banks remain the near exclusive providers of C\&I loans to small- and medium-sized firms, which continue to be highly illiquid. According to the 2012Q4 Financial Accounts, banks hold $37 \%$ of C\&I loans to nonfinancial corporations, but $86 \%$ of C\&I loans to nonfinancial noncorporate businesses, which tend to be much smaller.

\subsubsection{The cross-section of intermediary types}

Prediction 4 suggests that in the cross-section of intermediary types we should see a strong positive relationship between $A \_I L L I Q U I D_{j}$ and $L \_S T I C K Y_{j}$. Because the stickiness of liabilities as opposed to their contractual maturity is the key to avoiding costly liquidations, we expect to see a weaker relationship between $A_{-} I L L I Q U I D_{j}$ and $L_{-} M A T U R I T Y_{j}$. In particular, we expect traditional banks to look like an extreme outlier in this regard because their assets are highly illiquid given the short contractual maturity of their liabilities.

Panel A of Fig. 4 plots $A \_I L L I Q U I D_{j}$ versus $L_{-} S T I C K Y_{j}$. As predicted by the theory, we see a strong positive relationship and the estimated regression is

$$
A \_I L L I Q U I D_{j}=0.13+\underset{(t=5.02)}{0.55} \times L_{-} S T I C K Y_{j}, R^{2}=0.64 .
$$

\footnotetext{
${ }^{22}$ See https://www.fdic.gov/regulations/capital/Community_Bank_Guide_Expanded.pdf for current risk weights.

${ }^{23}$ For instance, according to the Financial Accounts, commercial banks held $85 \%$ of the $\$ 750$ billion in second-lien home mortgage loans as of $2012 \mathrm{Q} 4$
} 
Panel B of Fig. 4 plots $A_{-}$ILLIQUID $D_{j}$ versus $L_{-}$MATURITY . The estimated regression is

$$
A_{-} \text {ILLIQUID }{ }_{j}=0.27+\underset{(t=1.59)}{0.36} \times L_{-} \text {MATURITY }_{j}, R^{2}=0.29 .
$$

So, as expected, the regression fit deteriorates significantly from Panel A to Panel B. Although there is a general tendency for intermediaries with longer maturity liabilities to hold more illiquid assets, banks are a significant outlier. Relative to other patient investors, who obtain stable funding by issuing liabilities with long contractual maturities, banks issue short-term liabilities but organize themselves in such a way that their contractually short-term deposits are de facto extremely stable.

\subsection{Related microevidence}

While we have focused on the aggregate structure of financial intermediation, the banking literature contains some complementary micro evidence consistent with our theory. Using the Survey of Terms of Business Lending, Berlin and Mester (1999) find that, in the cross-section of banks, those with greater access to sticky "core" deposits (i.e., transaction and saving deposits) are more likely to form stable lending relationships with firms, providing borrowers with insurance against transitory market shocks. Black et al. $(2007,2010)$ find that banks with a large supply of core deposits tend to specialize in more illiquid information-intensive loans, whereas banks which are more reliant on wholesale funding tend to specialize in easy-to-value loans. ${ }^{24}$

\section{Optimal haircuts}

A central set of issues in current discussions of financial regulation concerns the migration of intermediation activity from the traditional banking sector to the shadow banking sector. In our model, shadow banking creates negative externalities because the social costs of fire sales exceed the private costs. This is the case because the ability of shadow banks to create money-like claims is constrained by the time-1 liquidation value of their collateral. An intermediary that switches from traditional to shadow banking fails to internalize how this switch reduces liquidation prices and thus the feasible amount of money creation by other shadow banks.

If it is also possible to create some private money via traditional banking (i.e., if $z_{i}>0$ ), the equilibrium size of the shadow banking sector is too large and the traditional banking sector is too small, as compared to the social optimum. The social optimum may be restored using a set of minimum required haircuts on shadow banks, which pushes money creation back towards traditional banks. These regulatory haircuts are effectively an extra capital requirement that the shadow banking sector must set aside when raising short-term funding against risky assets, above and beyond what the private sector demands to make the short-term claims safe. An additional haircut of $h_{i}$ only allows shadow banks to create $\left(k_{i}-h_{i}\right) F_{i}<k_{i} F_{i}$ of safe money-like claims using the risky asset $i$ as collateral. These haircuts function as a Pigouvian tax on the fire-sale externality associated with the shadow banking sector.

In the Internet Appendix, we show that if there are no social costs associated with the provision of government deposit insurance, these optimal shadow banking haircuts, given by $h_{i}^{* *}$, have a simple and intuitive form:

$$
h_{i}^{* *}=\frac{\eta\left(\varphi_{i}\right)}{1-\eta\left(\varphi_{i}\right)} \frac{z_{i}}{F_{i}}>0
$$

Here, $\eta\left(\varphi_{i}\right)$ denotes the elasticity of the fire-sale discount with respect to liquidation volume which is an increasing function of asset illiquidity $\varphi_{i}$. Optimal haircuts depend on two factors. First, the required haircut is higher for more illiquid assets. This is natural since $\eta\left(\varphi_{i}\right)$ captures the severity of the fire-sale externality and the strength of the over-migration tendency. Second, the optimal haircut is higher for assets with high values of $z_{i}$, namely, those with less fundamental risk. These are the assets with which traditional banks' stable, hold-to-maturity strategy can create the most monetary services. If traditional banking does not create any uninternalized costs, one wants to lean most aggressively against shadow banking in cases where traditional banks provide an efficient alternative. ${ }^{25}$

Of course, traditional banking also gives rise to costs that are not fully internalized. Since bank capital is completely wiped out in the disaster state of the world, creating safe bank deposits inevitably exposes taxpayers to some tail risk. This exposure is socially costly to the extent that deposit insurance creates moral hazard problems, government fiscal capacity is limited (Stavrakeva, 2013), or banks do not fully understand tail risks (Gennaioli, Shleifer, and Vishny, 2012, 2013).

In the Internet Appendix we assume that these insurance payouts are financed by distortionary taxes which create deadweight social losses. In this case, the optimal haircut in (25) is reduced by a term that reflects the marginal fiscal cost of relying on taxpayer-financed deposit insurance. This cost is greater when the disaster state is more likely, when the scale of

\footnotetext{
${ }^{24}$ Black, Hancock, and Passmore (2007) show that there is strong positive association between core deposit-taking and small business lending, while Black, Hancock, and Passmore (2010) find a similar connection between core deposits and information-intensive (i.e., subprime) mortgage lending.

${ }^{25}$ For example, our model implies that $h_{i}^{* *}=0$ for equity-like assets where $z_{i}=0$-in other words, there is no need for regulation in this case. This is because when $z_{i}=0$, shadow banking is the only technology for creating money-like claims, so there is no scope for over-migration. However, when $z_{i}>0$, there is also a stable banking technology (which is socially costless by assumption) to migrate away from.
} 
the resulting bailout is larger (i.e., when the traditional banking system is larger), and when a given amount of taxation creates greater deadweight losses.

\section{Conclusion}

The specialness of traditional banks comes from combining stable money creation on the liability side with assets that have relatively low-risk, long-run cash flows but possibly volatile market values and limited liquidity. To make this business model work, banks rely on deposit insurance and hold substantial equity capital.

Some preliminary evidence is consistent with the model's predictions. Historically, prior to the introduction of deposit insurance, US commercial banks relied on deposits as their primary source of funding-just as they do today-but invested in assets that were much shorter-term and less volatile than they do now. The change in the structure of bank assets, and not just in the stability of their deposits, as a result of deposit insurance, is a distinctive prediction of our model.

In the cross-section of fixed-income assets, the most illiquid assets have the highest share held by commercial banks. As the model predicts, banks specialize in holding relatively low-risk fixed-income assets but are not afraid of illiquidity. In a cross-section of financial intermediary types, intermediaries with stickier liabilities hold less liquid assets. Banks, in particular, appear as having extremely sticky liabilities as well as very illiquid assets. More casual evidence, such as the near absence of both Treasuries and equities in bank asset portfolios, also supports our view.

One key message of the paper is that the structure of financial intermediation may be shaped in important ways by the nonfundamental movements in asset prices-due to fire sales, noise trading, slow-moving capital, and other frictions-that have been extensively documented in the asset-pricing literature. Specifically, one central role of intermediaries-and of banks in particular-is to act as a bridge between households who want to put their money in a safe place that they do not need to watch, and securities markets where even assets with relatively low fundamental risk can have volatile market prices.

\section{References}

Bai, J., Krishnamurthy, A., Weymuller, C.H., 2015. Measuring liquidity mismatch in the banking sector. Unpublished working paper. Georgetown University, Northwestern University, and Harvard University.

Basel Committee on Banking Supervision, 2010. Basel III: International framework for liquidity risk measurement, standards and monitoring. 〈http://www. bis.org/publ/bcbs188.pdf $)$.

Basel Committee on Banking Supervision, 2013. Basel III: The liquidity coverage ratio and liquidity risk monitoring tools. 〈http://www.bis.org/publ/bcbs238.pdf〉.

Berlin, M., Mester, L.J., 1999. Deposits and relationship lending. Review of Financial Studies 12, 579-607.

Black, L.K., Hancock, D., Passmore, W., 2007. Bank core deposits and the mitigation of monetary policy. FEDS working paper 2007-65. Federal Reserve Board of Governors.

Black, L.K., Hancock, D., Passmore, W., 2010. The bank lending channel of monetary policy and its effect on mortgage lending. FEDS working paper 2010-39. Federal Reserve Board of Governors.

Board of Governors of the Federal Reserve System, 1943. In: Banking and Monetary Statistics, 1919-1941Publications Services of the Board of Governors, Washington, DC.

Board of Governors of the Federal Reserve System, 1959. All Bank Statistics, United States, 1896-1955. Publications Services of the Board of Governors, Washington, DC.

Bolles, A., 1890. The National Bank Act and its Judicial Meaning. Homans Publishing Company, New York.

Brunnermeier, M.K., Gorton, G., Krishnamurthy, A., 2014. Liquidity mismatch measurement. In: Brunnermeier, M., Krishnamurthy, A. (Eds.), Risk Topography, University of Chicago Press, Chicago, IL, pp. 99-112.

Calomiris, C.W., Gorton, G., 1991. The origins of banking panics: models, facts, and bank regulation. In: Hubbard, R.G. (Ed.), Financial Markets and Financial Crises, NBER, University of Chicago Press, pp. 109-173.

Champ, B., 2007. The National Banking System: empirical observations. Working paper 07-19. Federal Reserve Bank of Cleveland.

Chernenko, S., Sunderam, A., 2014. Frictions in shadow banking: evidence from the lending behavior of money market funds. Review of Financial Studies 27, 1717-1750.

Cochrane, J.H., 2011. Discount rates. Journal of Finance 66, 1047-1108.

Coval, J., Jurek, J., Stafford, E., 2009. Economic catastrophe bonds. American Economic Review 99, $628-666$.

Dang, T.V., Gorton, G., Holmström, B., 2013. Ignorance, debt and financial crises. Unpublished working paper. Columbia University, Yale University, and Massachusetts Institute of Technology.

DeAngelo, H., Stulz, R.M., 2015. Liquid-claim production, risk management, and bank capital structure: why high leverage is optimal for banks. Journal of Financial Economics 116, 219-236.

DeLong, J.B., Shleifer, A., Summers, L.H., Waldmann, R.J., 1990. Noise trader risk in financial markets. Journal of Political Economy 98 , $703-738$.

Diamond, D.W., 1984. Financial intermediation and delegated monitoring. Review of Economic Studies 51, $393-414$.

Diamond, D.W., 1997. Liquidity, banks, and markets. Journal of Political Economy 105, 928-956.

Diamond, D.W., Dybvig, P., 1983. Bank runs, deposit insurance, and liquidity. Journal of Political Economy 91, $401-419$.

Diamond, D.W., Rajan, R.G., 2001. Liquidity risk, liquidity creation and financial fragility: a theory of banking. Journal of Political Economy 109, 287-327.

Diamond, D.W., Rajan, R.G., 2011. Fear of fire sales, illiquidity seeking, and credit freezes. Quarterly Journal of Economics 126, 557-591.

Friedman, M., Schwartz, A.J., 1963. A Monetary History of the United States. Princeton University Press/NBER, Princeton, NJ.

Galbraith, J.K., 1954. The Great Crash. Houghton Mifflin, New York1929.

Gatev, E., Strahan, P.E., 2006. Banks' advantage in hedging liquidity risk: theory and evidence from the commercial paper market. Journal of Finance 61, $867-892$.

Gennaioli, N., Shleifer, A., Vishny, R.W., 2012. Neglected risks, financial innovation, and financial fragility. Journal of Financial Economics 104, 452-468.

Gennaioli, N., Shleifer, A., Vishny, R.W., 2013. A model of shadow banking. Journal of Finance 68, 1331-1363.

Gorton, G., Metrick, A., 2011. Securitized banking and the run on repo. Journal of Financial Economics 104, 425-451.

Gorton, G., Pennacchi, G., 1990. Financial intermediaries and liquidity creation. Journal of Finance 45, 49-71.

Greenwood, R., Hanson, S.G., 2013. Issuer quality and corporate bond returns. Review of Financial Studies 26, $1483-1525$.

Greenwood, R., Hanson, S.G., Stein, J.C., 2015. A comparative-advantage approach to government debt maturity. Journal of Finance.

Holmström, B., Tirole, J., 1997. Financial intermediation, loanable funds, and the real sector. Quarterly Journal of Economics 112, 663-691. 
Ivashina, V., Scharfstein, D.S., 2010. Bank lending during the financial crisis of 2008. Journal of Financial Economics 97, 319-338.

Jacklin, C.J., 1987. Demand deposits, trading restrictions, and risk sharing. In: Prescott, E.C., Wallace, N. (Eds.), Contractual Arrangements for Intertemporal Trade, University of Minnesota Press, Minneapolis, MN, pp. 26-47.

James, J.A., 1978. Money and Capital Markets in Postbellum America. Princeton University Press, Princeton, NJ.

Kacperczyk, M., Schnabl, P., 2013. How safe are money market funds? Quarterly Journal of Economics 128, 1073-1122.

Kashyap, A.K., Rajan, R.G., Stein, J.C., 2002. Banks as liquidity providers: an explanation for the co-existence of lending and deposit-taking. Journal of Finance 57, 33-73.

Krishnamurthy, A., Nagel, S., Orlov, D., 2014. Sizing up repo. Journal of Finance 69, 2381-2417.

Krishnamurthy, A., Vissing-Jorgensen, A., 2015. The Impact of Treasury supply on financial sector lending and stability. Unpublished working paper. Stanford University and University of California Berkeley.

Meltzer, A.H., 2002. A History of the Federal Reserve, Volume 1, 1913-1951. University of Chicago Press, Chicago, IL.

Miller, M.H., 1977. Debt and taxes. Journal of Finance 32 (2), 261-275.

Modigliani, F., Miller, M.H., 1958. The cost of capital, corporation finance and the theory of investment. American Economic Review 48, $261-297$.

Moen, J., Tallman, E., 1990. Lessons of the panic of 1907. Federal Reserve Bank of Atlanta Economic Review, May/June.

Moreira, A., Savov, A., 2014. The macroeconomics of shadow banking. New York University Working Paper.

Moulton, H.G., 1918. Commercial banking and capital formation. Journal of Political Economy 26 (May, June, July, November), 484-508, 638-663, 705-631, 849-881.

Myers, M.G., 1931. The New York Money Market, Volume I: Origins and Development. Columbia University Press, New York.

Pennacchi, G., 2012. Narrow banking. Annual Review of Financial Economics 4, 141-159.

Pollock, A.J., 1993. Banks and real estate: writing rules from the National Banking Act of 1863 to now. American Banker, February 5.

Shleifer, A., Vishny, R.W., 1992. Liquidation values and debt capacity: a market equilibrium approach. Journal of Finance 47 (4), $1343-1366$.

Shleifer, A., Vishny, R.W., 1997. The limits of arbitrage. Journal of Finance 52, 35-55.

Shleifer, A., Vishny, R.W., 2010. Unstable banking. Journal of Financial Economics 97 (3), 306-318.

Sprague, O.M.W., 1910. History of Crises Under the National Banking System. Publications of the National Monetary Commission. Government Printing Office, Washington, DC.

Stavrakeva, V., 2013. Optimal bank regulation and fiscal capacity. London Business School working paper.

Stein, J.C., 2012. Monetary policy as financial-stability regulation. Quarterly Journal of Economics 127 (1), 57-95.

Sunderam, A., 2015. Money creation and the shadow banking system. Review of Financial Studies 28, 939-977.

White, E.N., 1998. Were banks special intermediaries in late nineteenth century America? Federal Reserve Bank of St. Louis Review (May/June 1998). 